\title{
Determination of Toxic Material Penetrations for Wildland Respirator Filters
}

FED $201 \%$

Kenneth Lawrence Foote

OSTI

\author{
MS Thesis
}

May 1994 


\section{DISCLAIMER}

This document was prepared as an account of work sponsored by an agency of the United States Government. Neither the United States Government nor the University of California nor any of their employees, makes any warranty, express or implied, or assumes any legal liability or responsibility for the accuracy, completeness, or usefulness of any information, apparatus, product, or process disclosed, or represents that its use would not infringe privately owned rights. Reference herein to any-specific commercial product, process, or service by trade name, trademark, manufacturer, or otherwise, does not necessarily constitute or imply its endorsement, recommendation, or favoring by the United States Government or the University of California. The views and opinions of authors expressed herein do not necessarily state or reflect those of the United States Government or the University of California, and shall not be used for advertising or product endorsement purposes.

This report has been reproduced

directly from the best available copy.

Available to DOE and DOE contractors from the

Office of Scientific and Technical Information

P.O. Box 62, Oak Ridge, TN 37831

Prices available from (615) 576-8401, FTS 626-8401

Available to the public from the

National Technical Information Service

U.S. Department of Commerce

5285 Port Royal Rd.,

Springfield, VA 22161

Work performed under the auspices of the U.S. Department of Energy by Lawrence Livermore National Laboratory under Contract W-7405-ENG-48. 


\title{
Determination of Toxic Material Penetrations for Wildland Respirator Filters
}

\author{
Kennèth Lawrence Foote
}

A Thesis Presented to

The Faculty of the Department of Chemical Engineering

San Jose State University

In Partial Fulfillment

of the Requirements for the Degree

Master of Science

Manuscript date: May 1994

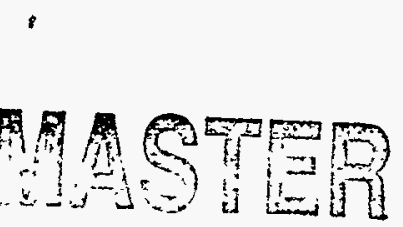

LAWRENCE LIVERMORE NATIONAL LABORATORY

University of California $\bullet$ Livermore, California $\bullet 94551$

DISTRIEUTIDN OF THS DOCUMENT IS UNLRAITED 

Thesis approved for the Department of Chemical Engineering

'Melame A.' mc. R.

Dr. M. A. McNeil, Thesis Advisor and Chairperson SISU, Department of Chemical Engineering

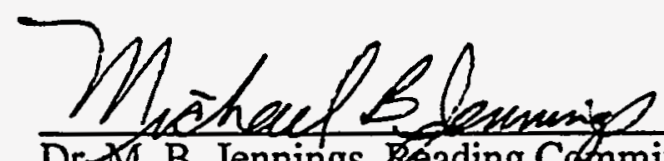

Dr. A. B. Jennings, Reading Committee Member SJSU, Department of Chemical Engineering

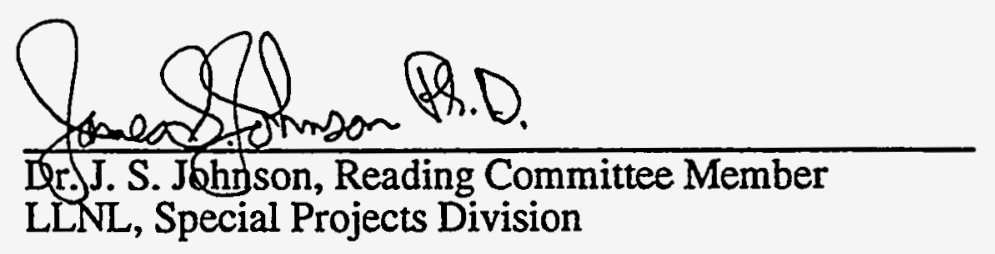

APPROVED FOR THE UNIVERSITY

Serena 9). Stanford
Date $1-3-94$

Date $3 J_{\text {AN }} 94$

Date $1-3-94$

Date $3 / 18 / 94$ 


\title{
ABSTRACT \\ DETERMINATION OF TOXIC MATERIAL PENETRATIONS FOR WILDLAND RESPIRATOR FILTERS
}

\author{
by Kenneth L. Foote
}

Thousands of wildland firefighters are exposed to high levels of toxic materials every year. Carbon monoxide, formaldehyde and acrolein gases, along with high particulate concentrations, are the major toxics encountered. Currently, the only respiratory protection wildland firefighters use is a bandanna over the mouth and nose. In this study, a modern activated carbon cartridge with an electrostatic prefilter was compared to a typical bandanna for its ability to filter wildland smoke toxics such as formaldehyde and particulates. The results of the tests were disappointing; neither filter performed very. well. The activated carbon cartridge and prefilter efficiently collected formaldehyde gas for up to 60 minutes; however, it only collected 85 percent of the challenge particulate. The bandanna, as expected, was only partially effective at collecting smoke particulate and filtered no toxic gases. 



\section{Acknowledgments}

I wish to thank Dr. M. A. McNeil and Dr. J. S. Johnson for their guidance and advice. Without the technical assistance of Don Beason and Scott Doughty this project could not have been completed. I would also like to thank Jeanine Cheng, Amalia Neidhardt and Steve Priante for their assistance during the chemical analysis. 



\section{Table of Contents}

\section{Page}

List of Figures

vii

List of Tables

viii

Chapter 1. Introduction

Chapter 2. Literature Review

Chapter 3. Hypothesis 13

Chapter 4. Materials and Methods 14

Chapter 5. Experimental Results 24

5.1 Reproducibility Data 24

5.2 Particle Size Data 29

5.3 Penetration Data 30

5.4 Breakthrough Data 33

5.5 Preliminary HEPA Filter Data 36

Chapter 6. Discussion 37

Chapter 7. Conclusions 43

References $\quad 45$

Appendix A. Discussion of Other Test Geometries 48

Appendix B. Tables of Experimental Data 49

Appendix C. Plots of Experimental Data 65 


\section{List of Figures}

Page

Figure 1. Bar chart of acres burned in U.S. wildland fires for 1983-88.

Figure 2. A schematic of the test chamber showing the sampling system.

Figure 3. Picture of the burner smoke production from a typical loading.

Figure 4. A typical gas chromatogram plot of an upstream smoke sample.

Figure 5. Plots of the burner mass loss for three identical activated carbon cartridge with prefilter tests.

Figure 6. Plots of the carbon monoxide concentration for three identical activated carbon cartridge tests.

Figure 7. Plots of the chamber exhaust gas temperature for three identical activated carbon cartridge tests.

Figure 8. Plots of the pressure differential across the test filter for the breakthrough test 10 .

Figure 9. Plot of the pressure across filter for the breakthrough test 9e showing 35 the plugging of the filter.

Figure 10. Plot of the pressure differential across the filter for the HEPA test. 36 


\section{List of Tables}

\section{Page}

Table 1. Table of chemical information and threshold limit values.

8

Table 2. Matrix of experimental parameters and the tests performed.

Table 3. A listing of the instrumentation used in this investigation.

Table 4. Impactor particulate size data upstream of the test filter.

Table 5. Impactor particulate size data downstream of the test filter.

Table 6. Particulate and formaldehyde penetration data.

Table 7. Formaldehyde breakthrough times. 



\section{Chapter 1.}

Introduction

Every summer the United States employs over 80,000 seasonal wildland firefighters ${ }^{1}$. These firefighters respond to approximately 70,000 fires per year. Even with this large force of personnel, an average of nearly 2,000,000 acres of land are burned every year. Figure 1 shows the total acres burned for the six years from 1983 through 1988, as recorded by the National Interagency Fire Coordination Center. As can be seen, in 1988 the United States experienced its worst fire season in 50 years. Over 5,000,000 acres were burned, about 2.5 times the average. This was due to several large fires in Yellowstone National Park ${ }^{2}$.

Wildland firefighters respond to a variety of fire types, not just forest fires. Wildlands consist of grasslands, forests, open range or a mixture of all three types. Wildland firefighters also conduct control burns over these types of terrain. Because of this variety of fires, wildland firefighters use different methods to attack fires than structural firefighters. Their job is very physically demanding. They are frequently required to hike several miles over steep terrain. They normally work on the fire line 8 to 12 hours, sometimes longer, enduring many hazards. In 1988, eleven wildland firefighters died on the job ${ }^{3}$. Heat and flames are obvious hazards. Falling trees and rocks also cause injury and death. A less obvious hazard is the inhalation of toxic gases created by the fire.

The health effects from breathing wildland smoke can be significant. Headaches are common complaints of wildland firefighters. Firefighters are more subject to bronchitis and pneumonia than the population as a whole. The antigenic effects of poison oak and 
poison ivy are not destroyed by fire. Breathing the smoke from one of these plants can kill someone who is sensitive to them. Rothman ${ }^{4}$ reports that a 3 percent drop in lung capacity can occur after one week of wildland fire fighting and there is evidence of permanent lung damage in wildland firefighters.

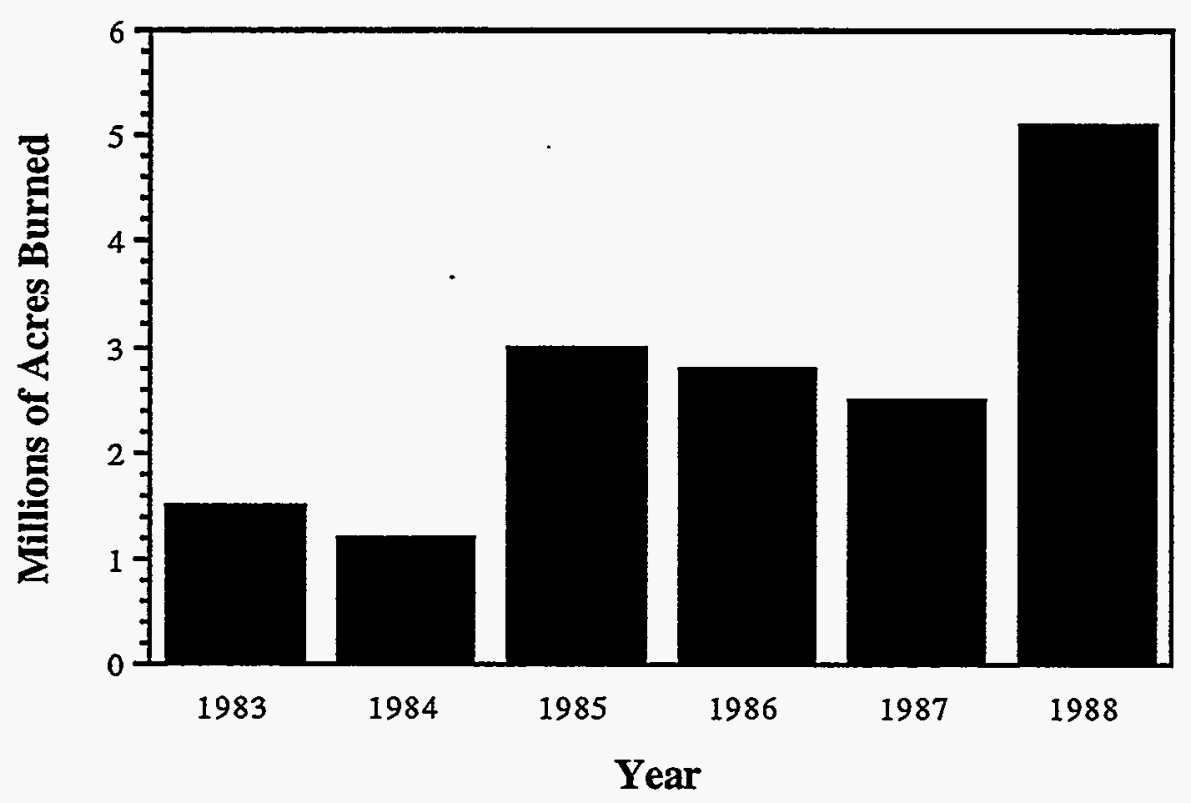

Figure 1. Bar chart of acres burned in U.S. wildland fires for 1983-88.

Incidents of debilitating wildland fire smoke exposure are increasing 3,5 as is awareness of the occupational health hazards. The continual lowering of toxic material Threshold Limits Values (TLV) is an example of this general increased awareness. TLV is the recommended average toxic chemical exposure concentration that is considered safe to be exposed to during an eight hour day. In 1993, the TLV of formaldehyde was 
lowered from $1.0 \mathrm{ppm}$ to $0.3 \mathrm{ppm}$. Table 1 lists the current TLV of several wildland smoke toxics. The yearly addition of new compounds to toxic lists is another example of the increased interest in occupational safety and health. In order to meet many of these reduced exposure limits, worker respiratory protection needs to improve.

Respiratory protection for wildland firefighters is unsophisticated. There is no respiratory equipment required by any current standard. Most wildland firefighters use a bandanna tied over their mouth and nose as the only protection against toxic materials. By standard respiratory practice, a bandanna is not adequate protection. Nevertheless, this has been the typical practice for the last 50 years. The solution, however, is not as simple as putting a respirator on every wildland firefighter.

Developing a wildland firefighter respirator is a difficult task. There are several factors to consider when attempting to provide respiratory protection for wildland firefighters. The wildland firefighters' effectiveness can not be compromised. They can not have significantly more physical burdens placed on them that might add to their direct risk from fire. Thus, heavy canisters of air or restrictive helmets are not viable solutions. The protection must be rugged and durable, due to the environment it will be exposed to in a wildland fire. Because of these constraints, it may be impossible to provide complete respiratory protection for wildland firefighters. However, there may be a more effective means of respiratory protection which does meet these physical constraints, other than a bandanna.

It may not be necessary to completely remove all the toxins in wildland smoke. A filter which removes the major toxic components can be a significant improvement. 
Furthermore, it may not be necessary to totally remove the toxic components. One criterion for an adequate wildland respirator would be to reduce the major toxic materials to below their TLV. Another criterion, which may be more applicable to wildland firefighters, would be to reduce the concentration of a toxic material to below the Short Term Exposure Limit (STEL) of the substance. The STEL is the recommended maximum 15 minute average exposure concentration that is considered safe.

In order to evaluate different wildland respirators, actual wildland fire smoke exposure concentrations need to be defined. Unfortunately, not much wildland smoke exposure data is currently available. Being at the right place at the right time to collect data can be very difficult. Predicting the occurrence of fires is nearly impossible. Wildland fires are a fast moving and variable phenomena. Because of the altitude and remoteness (e.g. mountain ranges) of the sampling locations, data collection is difficult.

Sampling smoke alone is not a simple thing to do. Smoke is a very complex and variable aerosol. Incomplete combustion produces hundreds of products. In the wildland environment, the fuel source (grass, brush, timber) is constantly changing as are the ambient conditions (wind, temperature and humidity). Wildland smoke has a large dust and soot component that can damage sampling equipment. Factors such as the long shifts firefighters work and whether or not they smoke cigarettes complicates gathering and analysis of exposure data. Also, wildland firefighters are frequently exposed to smoke during off-shift hours when they are not totally removed from the area of the fire. This additional off-shift exposure increases exposure values when data is collected long after the work shift. 
Because of these problems, much of the wildland smoke exposure data that has been previously collected is highly questionable. However, it still has some value quantitatively for trend analysis on wildland smoke exposure. Fortunately, new data is more thorough and reliable. The following section reviews the past and current literature on smoke toxins and smoke exposures. 
Until the 1980's, very little attention had been paid to the dangers of wildland smoke. Because of this, relatively little information has been gathered on the composition of wildland smoke and firefighter exposure. Wildland smoke contains many toxic materials. Several reports have identified the major components of wildland smoke in laboratory experiments 6-9. Carbon monoxide is the most common toxic component in smoke. Several aldehydes such as formaldehyde, acetaldehyde and acrolein are also found in significant concentrations. Formaldehyde is a common by-product of combustion. It is a colorless gas with a strong odor. Concentrations below $1 \mathrm{ppm}$ are detectable by humans. It is known to cause irritation of the eyes, respiratory tract and skin 10 . Formaldehyde is a suspected carcinogen. Acrolein, also called 2-propenal, has respiratory effects that are more severe than formaldehyde's effects ${ }^{11}$. Ten ppm concentrations of acrolein have been shown lethal in rats. Particulate is a generic name for all the aerosols found in wildland fire smoke including dust and soot particles. Particulate is of highly variable composition, particularly in wildland smoke. Benzene, a known carcinogen, as well as other complex aromatic hydrocarbons and Polycyclic Aromatic Hydrocarbons (PAHs) are found in smoke 7 .

Table 1 lists the TLV and toxic effects for several common wildland smoke components 12,13 . The TLV is the recommended average toxic exposure concentration that is considered safe to work around. A TLV is usually defined as an eight-hour Time Weighted Average (TWA). The TWA is the average airborne exposure concentration in any 8-hour work shift of a 40 -hour work week which shall not be exceeded. There are also ceiling concentrations that should never be exceeded. 
There is no recommended TLV concentration for wildland smoke particulate. The $\mathrm{TLV}$ for particulate is defined in $\mathrm{mg} / \mathrm{m}^{3}$. Dust particulate exposure limits 12 vary depending on the material, from $1 \mathrm{mg} / \mathrm{m}^{3}$ for wood dust to $10 \mathrm{mg} / \mathrm{m}^{3}$ for diatomaceous earth. Carbon black has a TLV of $3.5 \mathrm{mg} / \mathrm{m}^{3}$. Wildland smoke particulate is more toxic than any of these, since other toxic smoke constituents can be absorbed on its surface 25 .

Before 1980, most of the data on smoke exposure was for structural fires. More research was done on structural fires because they are more common than wildland fires 16,17 and present a greater threat to human life 3,5. Burgess 18 reports carbon monoxide concentrations up to $27,000 \mathrm{ppm}$ in structural fires. Treitman 19 reports peak acrolein concentrations of $100 \mathrm{ppm}$. He also observed particulate concentrations of $10,000 \mathrm{mg} / \mathrm{m}^{3}$. Gold 20 measured particulate concentrations with the Boston fire department and observed average particulate concentrations of only $22 \mathrm{mg} / \mathrm{m}^{3}$. These concentrations are higher than we would expect of wildland fires because of the increased oxygen starvation and the lack of dilution in structural fires. However, they do serve as a guideline and a possible upper bound on the expected species concentrations. The range of the reported particulate concentrations also demonstrates the difficulty in characterizing smoke composition.

The toxicity of the products of cellulose-based combustion is well established in laboratory experiments 6-9. One source of fuel often used in these small-scale tests is douglas fir ${ }^{14}$. In the laboratory, douglas fir smoke is a good approximation for the toxic products to which a wildland firefighter might be exposed. Hartzell 11 used douglas fir as the baseline material for comparative toxicity (i.e., more toxic than douglas fir or less 
Table 1. Table of chemical information and threshold limit values.

\begin{tabular}{|c|c|c|c|c|}
\hline & $\begin{array}{c}\text { Molecular } \\
\text { Weight }\end{array}$ & $\begin{array}{l}\text { Threshold } \\
\text { Limit } \\
\text { Value }\end{array}$ & $\begin{array}{l}\text { Short Term } \\
\text { Exposure } \\
\text { Limit }\end{array}$ & Health Effect \\
\hline Carbon dioxide & 44.00 & $5,000 \mathrm{ppm}$ & $30,000 \mathrm{ppm}$ & $\begin{array}{l}\text { headaches, } \\
\text { mild narcotic }\end{array}$ \\
\hline Carbon monoxide & 28.01 & $25 \mathrm{ppm}$ & Ceiling & odorless asphyxiant gas \\
\hline Formaldehyde & 30.03 & $0.3 \mathrm{ppm}$ & Ceiling & $\begin{array}{l}\text { irritates eyes and } \\
\text { respiratory tract, } \\
\text { suspected carcinogen }\end{array}$ \\
\hline Acetaldehyde & 44.05 & $25 \mathrm{ppm}$ & Ceiling & $\begin{array}{l}\text { headaches, } \\
\text { mild narcotic, } \\
\text { animal carcinogen }\end{array}$ \\
\hline Acrolein & 56.06 & $0.1 \mathrm{ppm}$ & $0.3 \mathrm{ppm}$ & $\begin{array}{l}\text { irritates eyes and } \\
\text { respiratory tract, } \\
\text { carcinogen }\end{array}$ \\
\hline Benzene & 78.12 & $0.1 \mathrm{ppm}$ & $0.3 \mathrm{ppm}$ & carcinogen \\
\hline $\begin{array}{l}\text { Particulate } \\
\text { (Diatomaceous earth) }\end{array}$ & variable & $10 \mathrm{mg} / \mathrm{m}^{3}$ & & irritates respiratory tract \\
\hline
\end{tabular}


toxic than douglas fir). Farrar 14 defined two mechanisms of toxic component action by douglas fir smoke on rats. High carbon monoxide concentrations incapacitated the majority of a test population. The remainder of the population was incapacitated by another mechanism called anoxic anoxia which is a lack of oxygen in the blood. This condition is caused by sensory irritants such as acrolein and formaldehyde which inhibit respiration.

Wildland fire research has increased since 1980. Reinhardt 25 has reported several hundred toxic compounds in actual wildland smoke, among them carbon dioxide, carbon monoxide, formaldehyde, acetaldehyde, acrolein, furfural and benzene. Several PAHs such as acridine, anthracene and pyrene were also found. Reinhardt also reports that PAHs are often found associated with smoke particulate matter.

The Equipment Development Center of Montana found carbon monoxide exposure levels of over $50 \mathrm{ppm}$ in 10 percent of 1661 personnel tested 21 . The U.S. Forest Service 22 reported carbon monoxide exposure levels of $26 \mathrm{ppm}$ and formaldehyde exposure levels of $0.2 \mathrm{ppm}$. The National Institute for Occupational Safety and Health (NIOSH) 23 measured carbon monoxide exposure levels of $23 \mathrm{ppm}$ at the 1988 Yellowstone fire. Unfortunately, this data is clouded in controversy as sampling methods and accuracy are questioned. Tobacco smoke from cigarettes interferes with the measurement of the carbon monoxide exposures, and many of those tested were smokers. For all of these tests, carboxyhemoglobin levels were measured long after the fire exposure. Thus, only TWA values are reported. No short term exposure data was collected. Few conclusions can be drawn from these data. 
In the last few years, more reliable data has been collected. Brotherhood et al. 24 reports low concentrations of carbon monoxide in controlled experimental Australian bush fires. The highest eight-hour average carbon monoxide concentration they observed was $50 \mathrm{ppm}$. The average of all the 8 hour exposures was $25 \mathrm{ppm}$. Careful attention was paid to correct for ambient carboxyhemoglobin from cigarette smoking. Unfortunately, in these tests alveolar air samples were taken at the end of an eight hour work shift. Thus, these tests also measured average exposure data and didn't measure transient exposure concentrations.

Matera et al. 26 has collected the most reliable wildland smoke exposure data to date. They collected time history data for carbon monoxide. This data reports several short term carbon monoxide exposures in excess of $300 \mathrm{ppm}$. Many of these exposures were from the exhaust of fire trucks used to transport wildland firefighters around the fire scene. In addition to time history carbon monoxide data, average exposure data for particulate and some toxic gases was collected. The average particulate exposure reported in this study was $40 \mathrm{mg} / \mathrm{m}^{3}$. Formaldehyde exposure data was collected and an average value of $0.3 \mathrm{ppm}$ was reported. Acrolein sampling was very limited and unreliable; however, the value reported was $0.05 \mathrm{ppm}$.

Reinhardt et al. 25 has done a thorough exposure study of wildland combustion products. They studied 16 actual wildland fire exposures over a one year period in California, Oregon and Washington. The data collected was for carbon dioxide, carbon monoxide, acrolein, formaldehyde, benzene, furfural, PAHs and particulate concentrations. Typical particulate concentrations were $10 \mathrm{mg} / \mathrm{m}^{3}$. Mean concentrations of formaldehyde of up to $2 \mathrm{ppm}$ were observed during direct fire attack activities. 
Acrolein concentrations of $0.3 \mathrm{ppm}$ were recorded. Bag samples of air showed carbon monoxide concentrations as high as $200 \mathrm{ppm}$. Carbon dioxide concentrations of 2000 ppm were observed.

From the available literature, it can be concluded that at current TLV's and STEL's, some type of respiratory protection is needed for wildland firefighters to insure a safe work environment. Acceptable levels and types of respiratory protection need to be determined. In addition, the effectiveness of traditional bandannas in filtering out toxic smoke products need to be established. It is generally accepted that bandannas aren't very efficient filters. However, no research has determined the effectiveness of cotton bandannas to filter out the toxic materials of wildland smoke. Since the amount of toxic materials in wildland smoke doesn't appear to be that much over the accepted level, in many cases even an inefficient bandanna may provide adequate protection. A sophisticated wildland respirator may not be worth the added cost or the increased firefighter encumbrance of added weight and reduced visibility.

Filter efficiency can be evaluated by determining toxic material penetration. Filters are rarely 100 percent efficient in removing a substance. Penetration is the ratio of the toxic concentration after the filter to the toxic concentration before the filter. Penetration is dependent on the environmental toxic concentration and the efficiency of the filter. To date no penetration data for wildland smoke filters has been reported. Recommended penetration values for firefighter applications are below 0.01 , or 99 percent efficient.

Another important characterization parameter for filters, such as activated carbon cartridges, is breakthrough time. These types of filters eventually become ineffective, 
because all the adsorption sites become filled, allowing additional chemicals to pass through without being absorbed. This phenomenon is called breakthrough. Breakthrough time is an important activated carbon cartridge parameter. If this type of filter has a breakthrough time significantly less than eight hours it will not be effective for a complete wildland firefighter work shift. An adequate wildland filter will need to be effective for at least eight hours, since wildland firefighters work long shifts and can not carry extra filters.

Filter plugging is similar to toxic gas breakthrough time. If the particle concentration in the smoke is high enough, a test filter can plug with particulate and be difficult to use. A filter is considered plugged at a pressure differential across the filter of 3 " of water (747 Pascals), the nominal value of comfortable human inhalation. Filter plugging is considered the particulate equivalent of chemical breakthrough.

In this study, an activated carbon cartridge with and without an electrostatic prefilter was compared to a typical bandanna for its ability to filter three wildland smoke toxics, formaldehyde, acrolein and particulate. The parameters of interest were toxic material penetration and toxic gas breakthrough time. 


\section{Chapter 3. Hypothesis}

The experimental hypothesis was that an activated carbon cartridge with an electrostatic prefilter will provide significant improvement in respiratory protection over a cotton bandanna by reducing inhaled particulate and toxic gases, such as acrolein and formaldehyde, to acceptable levels for wildland firefighters. A series of tests in a smallscale test chamber was conducted to determine the effectiveness of two wildland respirator filters. The measurements of interest were toxic material penetration and toxic gas breakthrough time. 
The determination of the penetration and breakthrough time of the toxic materials of actual smoke was done in a small-scale test chamber as shown in Figure 2. The dimensions of the chamber are $28 \times 32 \times 36$ inches. Two Hundred grams of Japanese Black Pine needles (Pinus thunbergii) were placed in a burner on a load cell in the chamber at the start of each test. These pine needles were gathered from the ground outside the test building in Livermore, $\mathrm{CA}$. The pine needles were dry and brown in color. The needles were ignited with a 10 second blast of a small propane torch. Within 2 minutes, a thick white smoke was produced. It should be noted that much less smoke was produced by these same pine needles during flaming combustion in other configurations. See Appendix A for discussion on alternative fuels and geometries. Figure 3 is a picture of the burner used and the resulting smoke from a typical pine needle loading. During testing, the burner inside the test chamber became obscured from view as the smoke filled the chamber. 200 grams of needles produced smoke for up to 60 minutes.

Room air was pulled into the test chamber by an exhaust fan controlled by a butterfly valve. Thus, the chamber ventilation rate could be set at several levels to generate different combustion product concentrations. The chamber ventilation rate was varied from $425 \mathrm{lpm}$ to $325 \mathrm{lpm}$. The chamber exhaust flow was measured with a sharp-edged orifice. As shown in Figure 2, a small portion of the chamber exhaust flow, designated the sample stream, was pulled through the test filter. The remainder of the chamber exhaust flow was exhausted to the building ventilation system. 


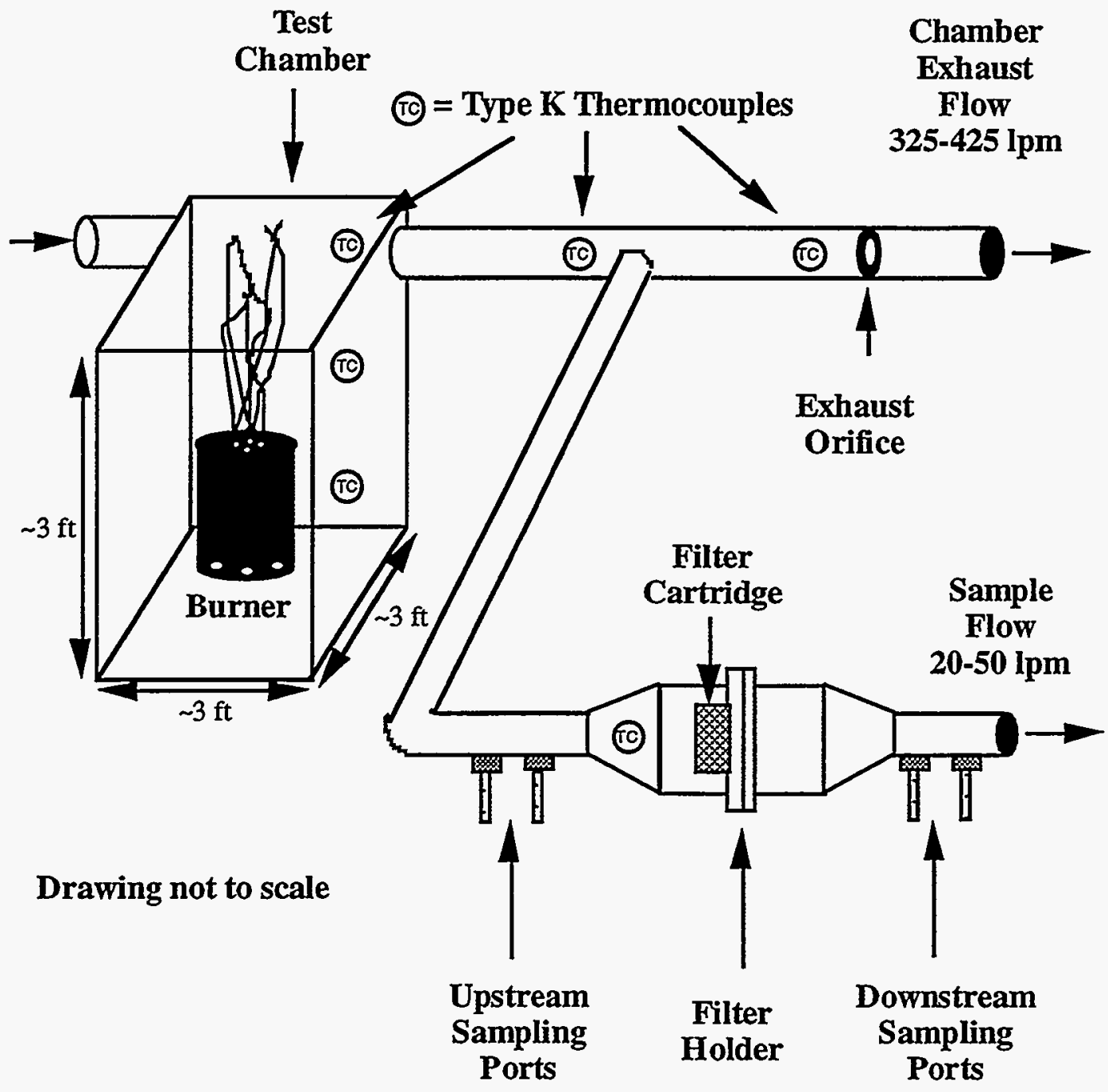

Figure 2. A schematic of the test chamber showing the sampling system. 


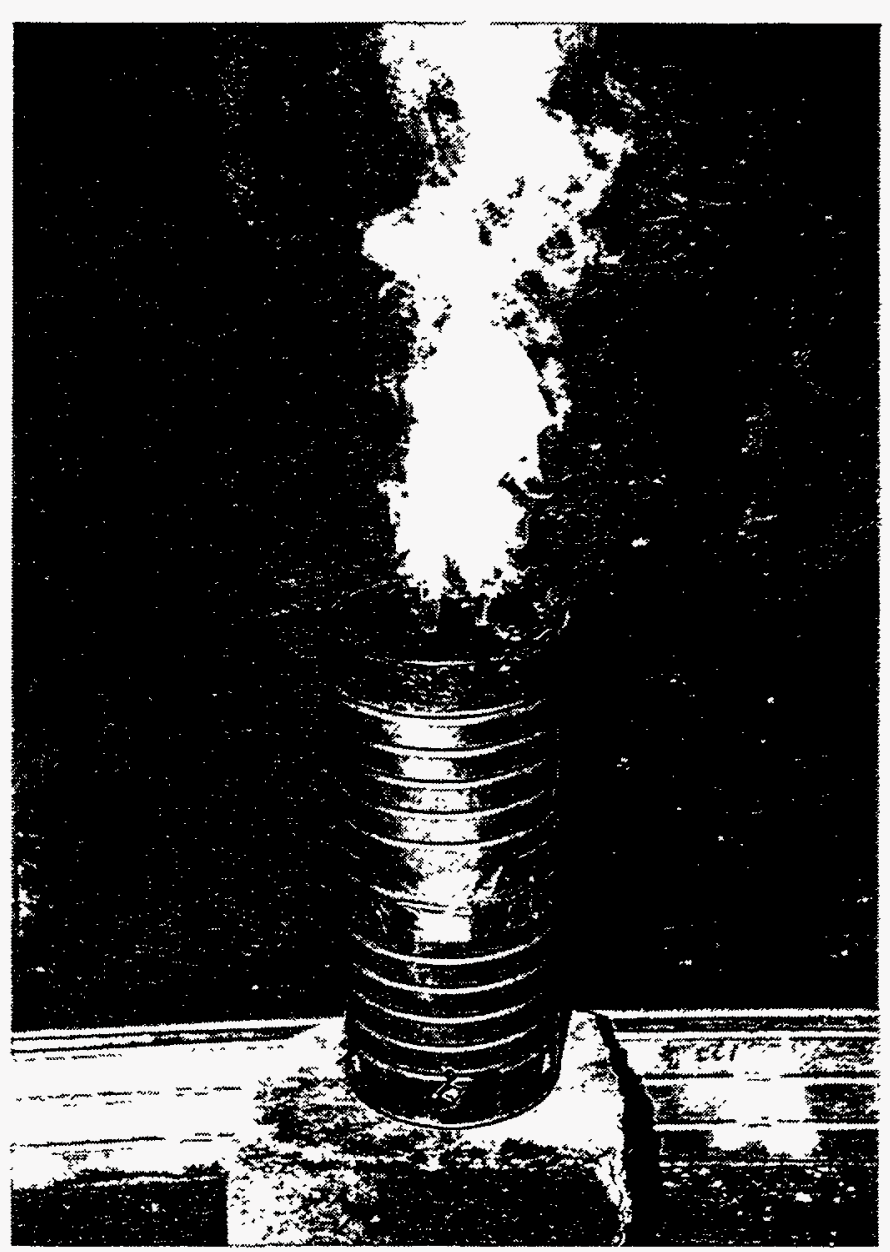

Figure 3. Picture of the burner smoke production from a typical loading. 
Two minutes after the pine needles were ignited by the propane torch, the sample stream was pulled through the test filter at either 20 or $50.1 \mathrm{pm}$. This simulated either moderate or fast respiration. Silverman determined the respiration rate for moderate work was $40 \mathrm{lpm} 27$. A flow rate of $20 \mathrm{lpm}$ through a single activated carbon cartridge represents the average human respiration rate during moderate work, since two activated carbon cartridges are used per respirator. A flow rate of $50 \mathrm{lpm}$ represents the human respiration rate during vigorous work such as fighting a wildland fire.

Particulate and aldehyde sampling was also initiated 2 minutes after ignition. Particulate and aldehyde sampling was performed before (upstream) and after (downstream) the test filter. The sampling period was 20 minutes long. Since the majority of the burner mass loss and smoke production occurred during this 20 minutes, it was chosen as the sample period. The burner continued to produce toxic material and smoke for up to 60 minutes, but at a reduced rate.

The concentrations of formaldehyde and acrolein in the sample stream were analyzed both upstream and downstream from the test filter. These concentrations were determined by pulling the sample stream through an ORBO-24 adsorbent tube. This tube contained 150 grams of XAD-2 media coated with 2-hydroxymethylpiperidine (2-HMP) which reacts selectively with aldehydes to form a stable oxazolidine derivative. The formaldehyde-oxazolidine and acrolein-oxazolidine derivatives were desorbed with toluene and analyzed on a Varian 3700 gas chromatograph (GC). The concentration in the sample stream was determined by calibration of the GC with known standards. Figure 4 is a typical gas chromatogram plot of a sample. The first set of peaks on the left are from the toluene solvent, with formaldehyde-oxazolidine appearing at 9.11 minutes 


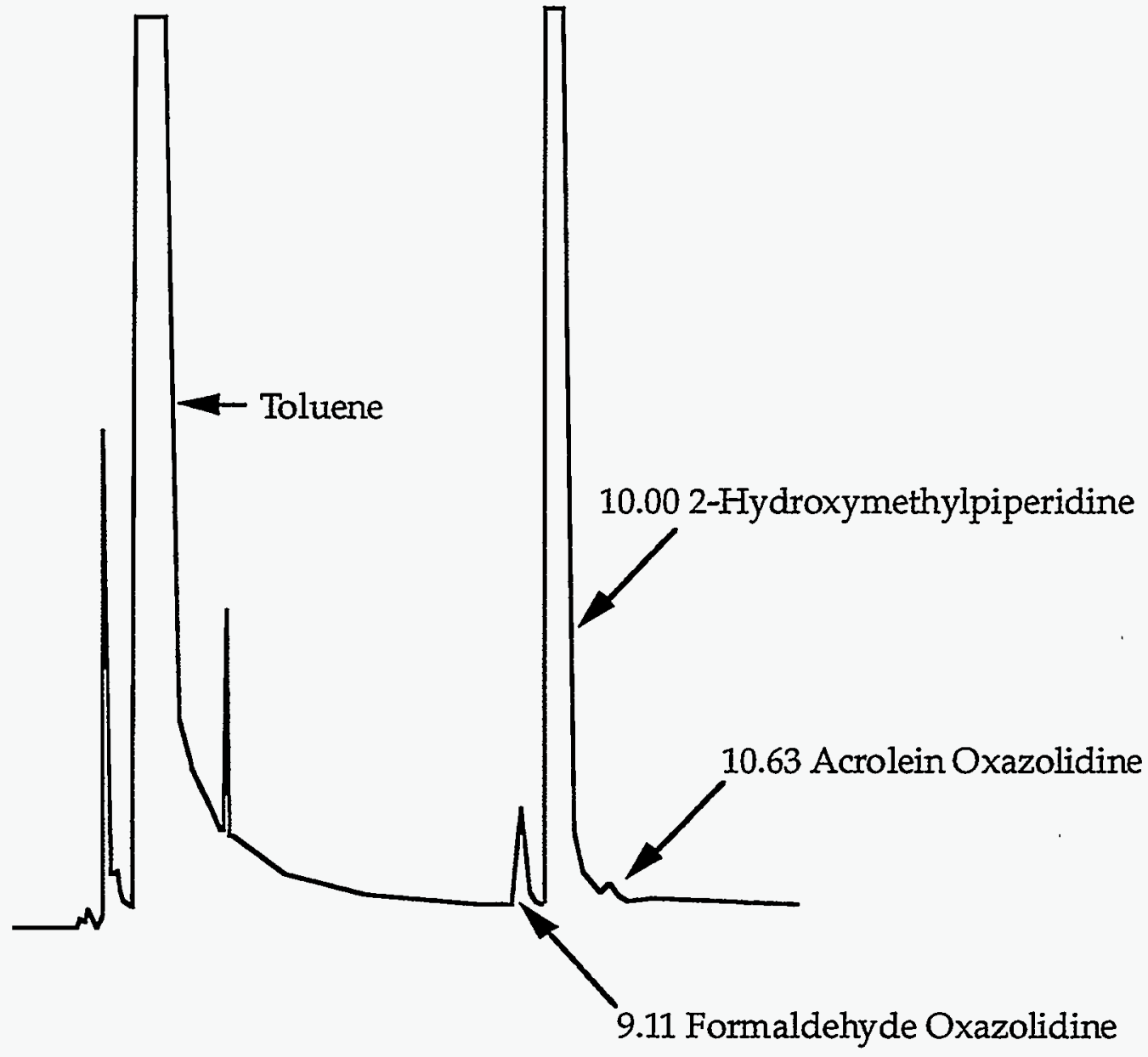

Figure 4. A typical gas chromatogram plot of an upstream smoke sample. 
followed by the large 2-HMP peak at 10.00 minutes. The last small peak on the right is acrolein-oxazolidine at 10.63 minutes. The detection limit of formaldehyde and acrolein was $1 \mathrm{ppm}$ as determined by internal standards. The calibration curves for the acrolein and formaldehyde analysis are in Appendix C.

Particle density measurements were obtained using glass fiber filters upstream and downstream of the test filter. Gelman type E $47 \mathrm{~mm}$ filters were used. Average mass densities were determined by weighing the absolute filters on a Mettler PM200 microbalance to \pm 0.001 grams. These filters were weighed immediately after sampling ended.

An Anderson impactor was used to determine the aerodynamic particle size of the smoke generated in the chamber. The smoke particles were sized by pulling them through successively smaller orifices and impacting them on stainless steel plates. Large particles were impacted on the first plates and smaller particles on later plates. A High Efficiency Particulate Airfilter (HEPA) filter was the final particle collection stage. The plates and the filter were weighed before and after to determine the amount of particulate collected. The Anderson impactor has eight stages and can size particles from 11 microns to 0.4 microns. Starting at 240 seconds after ignition, during the greatest mass loss of a test, a 60 second sample of smoke was taken from the chamber and drawn through the impactor.

An eight test fractional factorial test matrix was used to design experiments to determine toxic material penetration. Five parameters were investigated. Two types of filters were tested, bandanna and activated carbon filter with prefilter. The activated 
carbon cartridge was also tested in two configurations, with and without a prefilter. The cotton bandanna was tested in two geometries. A double or single thickness of cotton was mounted in an empty activated carbon cartridge. Two sample flow rates were tested, $20 \mathrm{lpm}$ and $50 \mathrm{lpm}$. Two chamber ventilation rates were tested, $325 \mathrm{lpm}$ and $45 \mathrm{lpm}$.

Two tests were done to evaluate formaldehyde breakthrough time and filter plugging for the activated carbon cartridges. For this evaluation repeated fires were necessary to provide exposure times longer than 20 minutes used in the penetration tests. For the formaldehyde breakthrough analysis over 4 hours of exposure was required. For these breakthrough tests, the sample flow through the test filter was stopped, the test chamber was opened, the burner removed and a new burner with fresh pine needles was installed and ignited. The sample flow through the test filter was restarted two minutes after the new burner was ignited. The test was to be terminated if no breakthrough of toxic materials occurred after eight hours of testing. However, all configurations tested resulted in breakthrough prior to eight hours of exposure.

In addition to the eight planned penetration tests using bandannas and activated carbon cartridges with electrostatic prefilters, a single preliminary penetration test was performed using an activated carbon cartridge in combination with a HEPA filter. Table 2 lists the experimental matrix for all the tests performed for this analysis: the eight penetration tests, the two breakthrough tests and the single preliminary HEPA penetration test.

Much of the data collected for the evaluation was gathered by a Hewlett-Packard 3497A data acquisition unit and recorded by a Hewlett-Packard model 200 computer. 
The scanner monitored 13 channels of type $\mathrm{K}$ thermocouples located in various locations around the test chamber as shown in Figure 2. Two Validyne P24 pressure transducers measured pressure across the test filter as well as the test chamber ventilation rate. A Transducers Inc. load cell model C462-10-10P1 measured the mass loss of the pine needles in the burner during the test. An Automated Custom Systems Model 3300 infrared carbon monoxide analyzer was used to measure carbon monoxide concentrations in the test chamber exhaust gas. The carbon monoxide monitor was calibrated with a known standard containing a carbon monoxide concentration of $1054 \mathrm{ppm}$. The carbon monoxide monitor has a rated accuracy of $\pm 10 \mathrm{ppm}$ at $1000 \mathrm{ppm}$. The measured full scale response time of the instrument was 10 seconds. Since the burner continued to produce smoke after the 20 minute sampling period, temperature, pressure, mass loss and carbon monoxide data were collected until carbon monoxide concentrations returned to baseline levels and no mass loss was observed. Approximately 40 minutes after sampling ended, the test was ended. Temperature, pressure, mass loss and carbon monoxide data were collected every 10 seconds throughout the 60 minute tests. Table 3 lists specific information on the instrumentation used for these experiments. 
Table 2. Matrix of experimental parameters and the tests performed.

The filter geometries tested: a cotton bandanna (single and double layer thickness) an activated carbon cartridge with and without prefilter

The test parameters varied:

fire ventilation rate (low and high, 325 and $425 \mathrm{lpm}$ ) simulated respiration rate (low and high, 20 and $50 \mathrm{lpm}$ )

A $2^{4-1}$ fractional factorial matrix yields eight tests.

Test 1: Single bandanna, high fire ventilation, low respiration rate Test 2: Single bandanna, low fire ventilation, low respiration rate Test 3: Double bandanna, high fire ventilation, low respiration rate

Test 4: Double bandanna, high fire ventilation, high respiration rate

Test 5: Cartridge without prefilter, high fire ventilation, low respiration rate Test 6: Cartridge without prefilter, low fire ventilation, low respiration rate Test 7: Cartridge with prefilter, high fire ventilation, low respiration rate Test 8: Cartridge with prefilter, high fire ventilation, high respiration rate

Test 9: Cartridge with prefilter, low fire ventilation, high respiration rate, 1 hour exposure

Test 10: Cartridge with prefilter, low fire ventilation, high respiration rate, 20 minute exposure

Test 11: Cartridge with HEPA filter, low fire ventilation, high respiration rate 
Table 3. A listing of the instrumentation used in this investigation.

Data Collection

Carbon Monoxide Sampling

Aldehyde Sampling

Gas Chromatograph

Pressure Measurements

Sample Flow Rate

Sample Weighing
HP 200 computer

HP 3497A Data Acquisition Unit

Automated Custom Systems

Model 3300

Infrared Analyzer (0-500 ppm CO)

Supelco ORBO-24 Tube

Varian Model 3700

(30 m X 0.53 I.D. DB17 nonpolar column)

Splitless Injection

Initial Temperature $=75^{\circ} \mathrm{C}$ for 5 minutes

Range $=75-140^{\circ} \mathrm{C}$ Rate $=10^{\circ} \mathrm{C} / \mathrm{min}$.

Validyne Model P24

Fischer Porter 1/2-17-6-10/55 Flowmeter

Transducers Inc.

Load Cell

Model C462-10-10P1

Doric Transducer Indicator

Model 420

Mettler Micro Balance

Model PM200 
The presentation of experimental results is divided into five sections. First, data validating the reproducibility of the tests is presented. This consists of mass loss data, temperature data and upstream toxic gas and particulate concentrations. Second, Anderson impactor particle size data is presented. Third, filter penetration data is presented. The penetration data consists of particulate penetration and formaldehyde penetration values. Next, the formaldehyde breakthrough time and filter plugging data are reported. Finally, some data from the preliminary HEPA test is presented.

\subsection{Reproducibility Data}

A blank test was performed where the pine needles were not ignited. No formaldehyde or carbon monoxide was detected in the chamber exhaust. No mass loss was observed during this blank test and the particulate filters did not collect any observable mass. This test was used to determine the accuracy of some of the instrumentation used for the experiments. The pressure measurements had a standard deviation of 5.7 Pascals. The standard deviation of a mass loss measurement was $1 . \dot{4} \mathrm{~g}$.

Figure 5 shows the burner mass loss with time for three identical activated carbon cartridge with prefilter tests. These mass loss curves are remarkably consistent, given that a random combustion process is occurring. Mass loss is a good indicator of the consistency of combustion data. The mass loss is a measure of the pyrolysis rate which drives the other parameters of interest such as the carbon monoxide, formaldehyde and particulate concentrations. The average rate of mass loss during the 20 minute sampling 
period for these tests was 6.5 grams/minute. Over 70 percent of the total mass loss for these tests occurred in the twenty minute sampling period. Appendix B-1 lists mass loss data for all the experiments done in this series.

The amount of carbon monoxide produced during the tests was consistent from test to test. Figure 6 shows the carbon monoxide concentration in the chamber exhaust gas during three similar tests. The maximum carbon monoxide concentration observed for these three tests was 2147, 2043 and 2172 ppm, respectively. The average carbon monoxide concentration for these three tests during the 20 minute sampling period was 1392 ppm. Appendix B-2 lists carbon monoxide data collected showing the highest or peak concentration of carbon monoxide observed during a test and average carbon monoxide concentrations during sampling.

The amount of formaldehyde detected upstream of the filter varied significantly. The upstream formaldehyde concentration for test $7 \mathrm{a}$, test $7 \mathrm{~b}$ and test $7 \mathrm{c}$ was $35 \mathrm{ppm}$. The formaldehyde concentration standard deviation of these three tests was $10 \mathrm{ppm}$. Appendix B-3 lists the formaldehyde data upstream and downstream of the test filter for each test. GC area counts are listed. Each GC sample was injected three times and the averaged area count was used for comparison. No acrolein data is presented here since little or none was detected.

Gas temperatures during these tests were low due to the high chamber ventilation rate and the slow combustion rate of the pine needles. The highest temperature observed was $57^{\circ} \mathrm{C}$. Figure 7 shows the chamber exhaust gas temperature for three identical activated carbon cartridge tests. Again, the reproducibility of the apparatus is observed. 


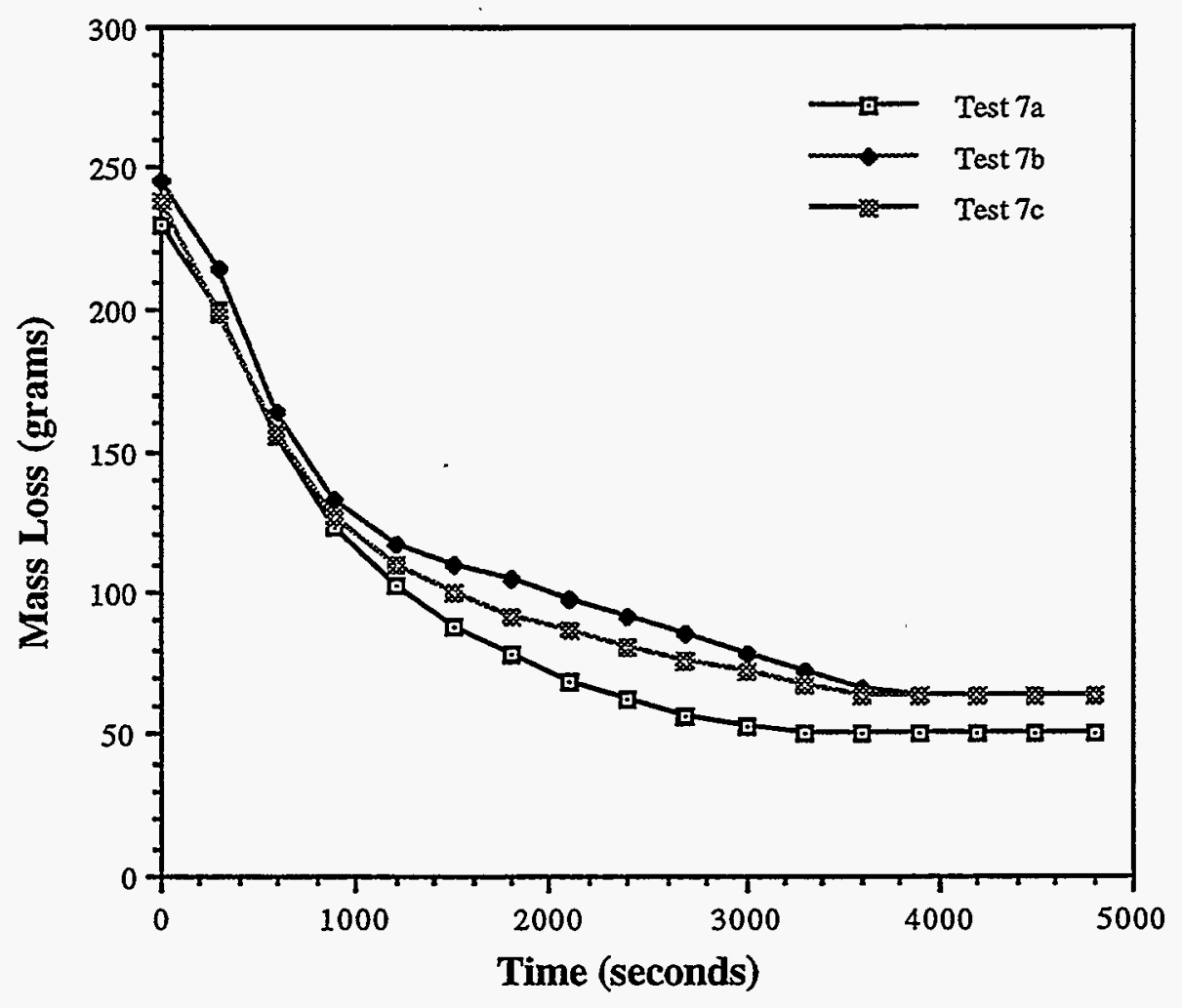

Figure 5. Plots of the burner mass loss for three identical activated carbon cartridge with prefilter tests. 


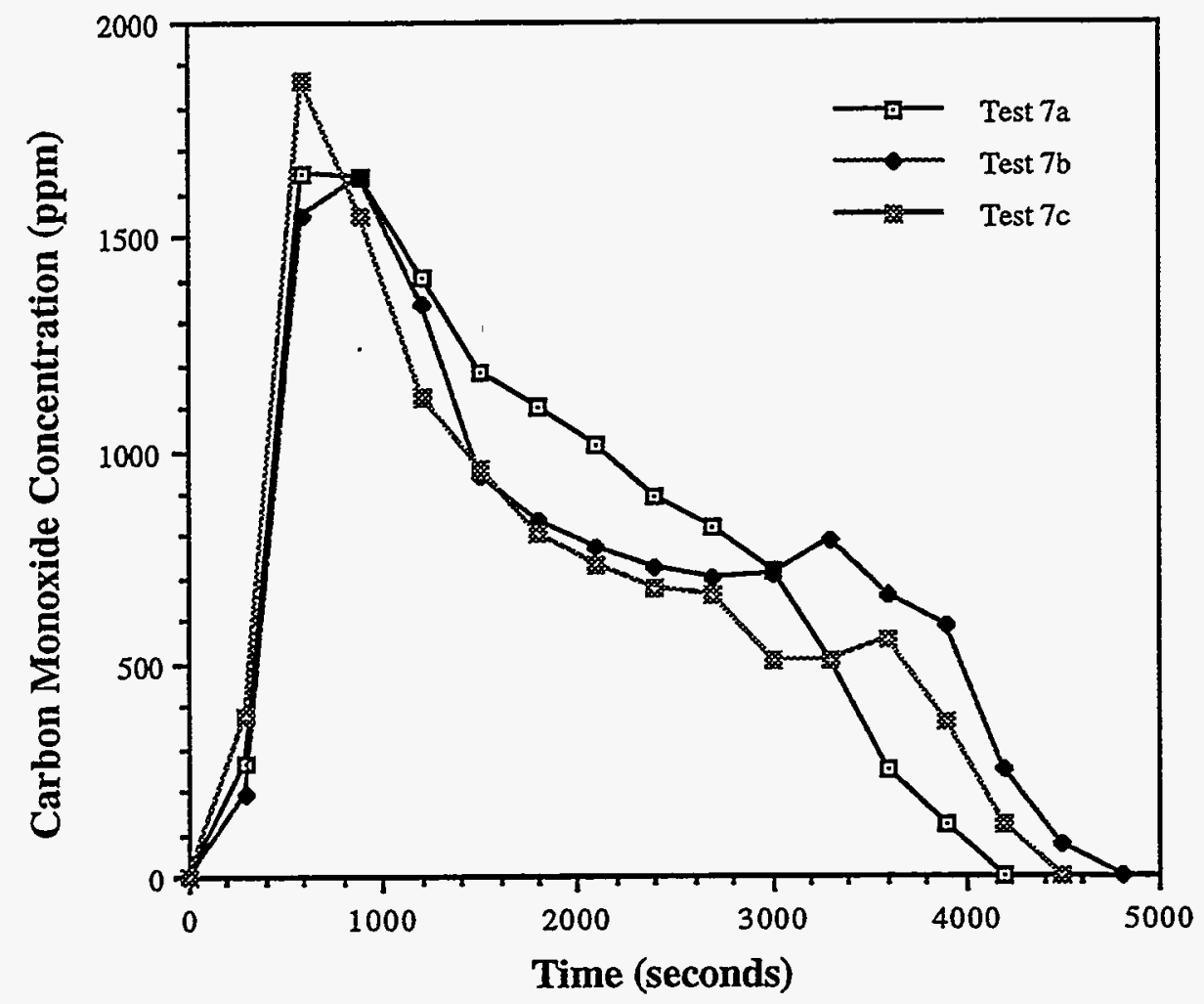

Figure 6. Plots of the carbon monoxide concentration for three identical activated carbon cartridge tests. 


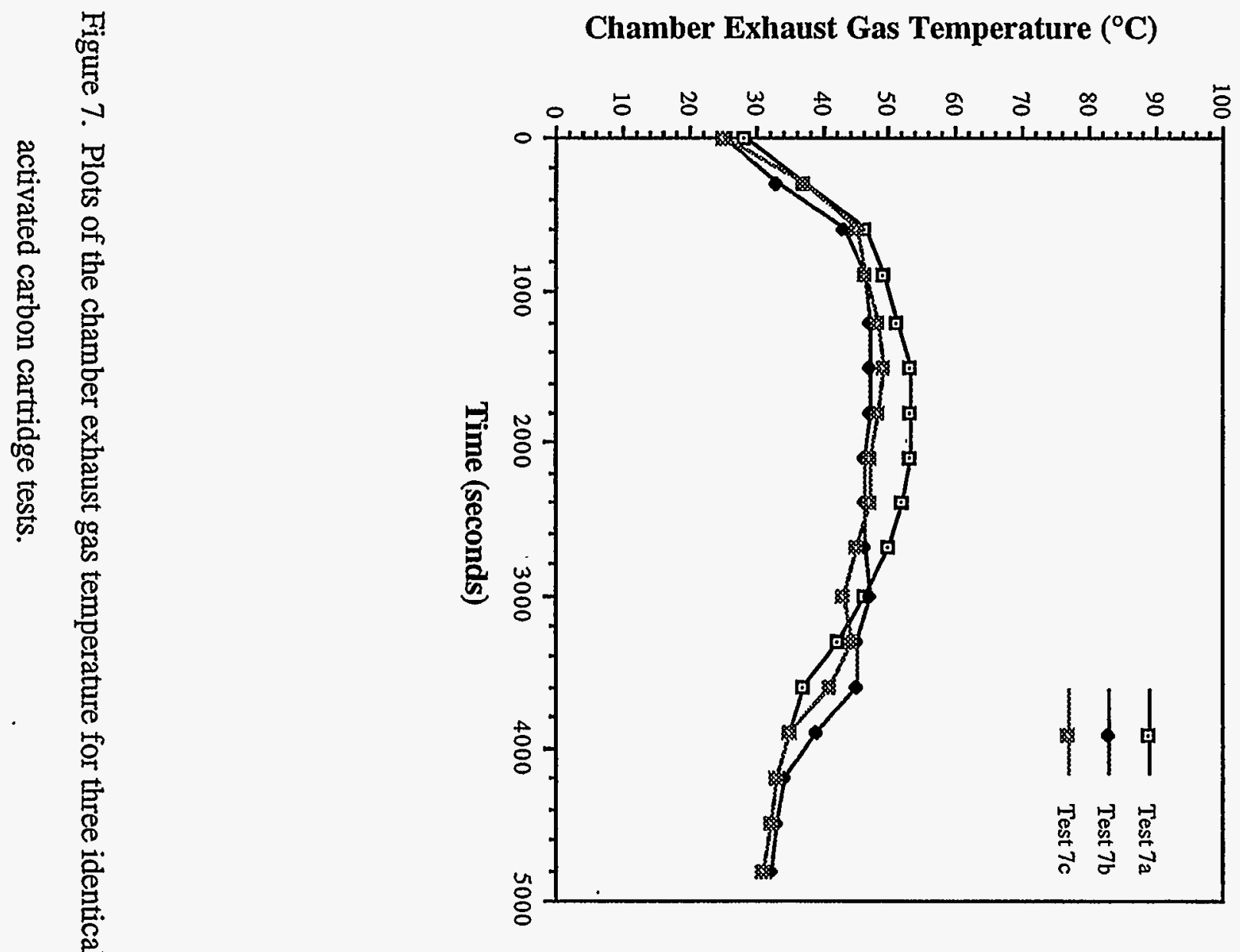


Appendix B-4 lists the thermocouple data collected. The observed temperature in the exhaust stream of the test chamber is presented in two forms, average temperatures during the sampling period and the peak or highest temperature observed during the entire test.

The average upstream particulate concentrations for tests $7 \mathrm{a}, \mathrm{b}, \mathrm{c}$ was $2.16 \mathrm{~g} / \mathrm{m}^{3}$ with a standard deviation of $0.03 \mathrm{~g} / \mathrm{m}^{3}$. The average downstream particulate concentrations for tests $7 \mathrm{a}, \mathrm{b}, \mathrm{c}$ was $0.33 \mathrm{~g} / \mathrm{m}^{3}$ with a standard deviation of $0.03 \mathrm{~g} / \mathrm{m}^{3}$. Appendix B-5 lists the particulate concentration data for all the tests. Appendix B-6 lists the pressure data across the test filter and across the exhaust flow orifice for each test.

\subsection{Particle Size Data}

Table 4 lists the Anderson impactor particle size data from a 60 second sample collected upstream of an activated carbon cartridge with prefilter. Due to the high concentration of particulate upstream of the test filter, Anderson impactor sampling times longer than 60 seconds were not practical, since the impactor would clog up with particulate. For this test, the average mass density of the upstream smoke was $3.14 \mathrm{~g} / \mathrm{m}^{3}$. Approximately 45 percent of the particulate was from 1.1 to 2.1 micron in aerodynamic diameter. Over 90 percent of the particles were from 0.7 to 3.3 microns in size. Table 5 lists the particle size data from a 20 minute sample collected downstream of an activated carbon cartridge with prefilter. The most abundant size of particles ranges from 0.7 to 1.1 micron. The average mass density of the downstream smoke was $0.33 \mathrm{~g} / \mathrm{m}^{3}$. Appendix C contains log-normal probability plots of the data in Tables 4 and 5. 


\subsection{Penetration Data}

Table 6 contains the particulate and formaldehyde data for the eight tests done to investigate penetration. The formaldehyde penetration data was difficult to analyze. For the activated carbon cartridge tests no formaldehyde was detected downstream of the filter and thus penetration values are impossible to calculate. The penetration values for the bandanna are questionable because the error in measuring the formaldehyde concentration is too large for this detailed a comparison. The formaldehyde measurement standard deviation of $10 \mathrm{ppm}$ is too large. For example, at a concentration of $40 \mathrm{ppm}$, this represents a possible error of 50 percent. This large error makes it possible to calculate formaldehyde penetrations greater than 1.00 which are invalid. The calculated penetration for test 4 is 1.16 . No conclusions can be drawn from the formaldehyde penetration data.

The particulate penetration data is more informative. The average particulate penetration for the single layer bandanna was 0.89 and for the double layered bandanna it was 0.87 . This is an apparent improvement between the single and double layered bandanna. Unfortunately, it is not a statistically significant difference, given the error of the measurement.

The particulate penetration through the activated carbon cartridge by itself was 0.45 and with the prefilter it was 0.15 . The activated carbon cartridge traps more particles than the bandanna. The addition of the prefilter reduces the penetration of smoke particles even more. However, this is a small improvement. Acceptable penetration values are an order of magnitude lower, approximately 0.01 . 
Table 4. Impactor particulate size data upstream of the test filter.

$\begin{array}{lcccccc}\text { Stage } & \begin{array}{c}\text { Initial } \\ \text { Mass } \\ (\mathrm{g})\end{array} & \begin{array}{c}\text { Final } \\ \text { Mass } \\ (\mathrm{g})\end{array} & \begin{array}{c}\text { Net } \\ (\mathrm{g})\end{array} & \begin{array}{c}\text { Percent } \\ \text { Mass }\end{array} & \begin{array}{c}\text { Lower } \\ \text { Limit } \\ \text { (micron) }\end{array} & \begin{array}{c}\text { Upper } \\ \text { Limit } \\ \text { (micron) }\end{array} \\ 0 & 22.2088 & 22.2089 & 0.0001 & 0.10 \% & >11 & \\ 1 & 19.2965 & 19.2966 & 0.0001 & 0.10 \% & 7 & 11 \\ 2 & 22.2654 & 22.2655 & 0.0001 & 0.10 \% & 4.7 & 7 \\ 3 & 28.1147 & 28.1148 & 0.0001 & 0.10 \% & 3.3 & 4.7 \\ 4 & 22.1018 & 22.1134 & 0.0116 & 11.42 \% & 2.1 & 3.3 \\ 5 & 21.9353 & 21.9963 & 0.0610 & 60.04 \% & 1.1 & 2.1 \\ 6 & 20.4735 & 20.4967 & 0.0232 & 22.83 \% & 0.7 & 1.1 \\ 7 & 28.1629 & 28.1670 & 0.0041 & 4.04 \% & 0.4 & 0.7 \\ \text { HEPA } & 0.1245 & 0.1258 & 0.0013 & 1.28 \% & & <0.4 \\ & \text { total mass collected }= & 0.1016 & 100.00 \% & & \end{array}$

Table 5. Impactor particulate size data downstream of the test filter.

$\begin{array}{lcccccc}\text { Stage } & \begin{array}{c}\text { Initial } \\ \text { Mass }\end{array} & \begin{array}{c}\text { Final } \\ \text { Mass } \\ (\mathrm{g})\end{array} & \begin{array}{c}\text { Net } \\ \text { Mass } \\ (\mathrm{g})\end{array} & \begin{array}{c}\text { Percent } \\ \text { Weight }\end{array} & \begin{array}{c}\text { Lower } \\ \text { Limit } \\ \text { (micron) }\end{array} & \begin{array}{c}\text { Upper } \\ \text { Limit } \\ \text { (micron) }\end{array} \\ 0 & 19.2963 & 19.2963 & 0.0000 & 0.00 \% & >11 & \\ 1 & 22.2088 & 22.2088 & 0.0000 & 0.00 \% & 7 & 11 \\ 2 & 22.2661 & 22.2663 & 0.0002 & 0.11 \% & 4.7 & 7 \\ 3 & 28.1132 & 28.1134 & 0.0002 & 0.11 \% & 3.3 & 4.7 \\ 4 & 22.1014 & 22.1055 & 0.0041 & 2.22 \% & 2.1 & 3.3 \\ 5 & 21.9351 & 21.9839 & 0.0488 & 26.39 \% & 1.1 & 2.1 \\ 6 & 20.4733 & 20.5680 & 0.0947 & 51.22 \% & 0.7 & 1.1 \\ 7 & 28.1622 & 28.1948 & 0.0326 & 17.63 \% & 0.4 & 0.7 \\ \text { HEPA } & 0.1236 & 0.1279 & 0.0043 & 2.33 \% & & <0.4 \\ & \text { total mass collected }= & 0.1849 & 100.00 \% & & \end{array}$


Table 6. Particulate and formaldehyde penetration data.

Test

Media

Test 1

Test $2 \mathrm{a}$

Test $2 b$

Test 3a

Test $3 b$

Test 4

Test 5

Test 6

Test 7a Activated Carbon Cartridge with Prefilter

Test $7 \mathrm{~b}$ Activated Carbon Cartridge with Prefilter

Test 7c Activated Carbon Cartridge with Prefilter

Test 8 Activated Carbon Cartridge with Prefilter
Particulate

Penetration

0.88

0.93

0.86

0.89

0.86

0.85

0.42

0.47

0.14

0.16

0.15

0.18
Formaldehyde

Penetration

0.87

0.75

0.71

0.77

0.80

1.16

Not Detected Not Detected

Not Detected

Not Detected

Not Detected

Not Detected ,

Table 7. Formaldehyde breakthrough times.

Test 9

Test 10a

Test 10b

Test 10c
180 minutes

60 minutes

50 minutes

50 minutes 


\subsection{Breakthrough Data}

Four breakthrough experiments were performed. Table 7 lists the formaldehyde breakthrough times of the activated carbon cartridges tested. Three replicates (test $10 \mathrm{a}, \mathrm{b}, \mathrm{c}$ ) were performed using repeated twenty minute exposures. One breakthrough experiment was performed using a 1 hour exposure. The 1 hour exposure experiment started with the normal 20 minute exposure, however, sampling continued for forty minutes longer. Breakthrough time was determined to the nearest 10 minutes by changing the downstream ORBO-24 tube every 10 minutes. The sample stream was pulled through the test filter at $50 \mathrm{lpm}$ for these experiments to reduce the required exposure time. Figure 8 is a plot of the pressure increase across the test filter for successive fires (test $10 a-a, b, c, d, e)$. The pressure across the filter increases with each successive smoke exposure.

Tests $9 \mathrm{a}, \mathrm{b}, \mathrm{c}, \mathrm{d}, \mathrm{e}$ were done using 1 hour sampling times. This experiment had a longer observed breakthrough time than the shorter exposure experiments due to the reduced average exposure concentrations as a result of the longer sample times. During test $9 \mathrm{e}$ the test filter was observed to plug. Figure 9 shows the pressure increase across the test filter for test $9 \mathrm{e}$. 


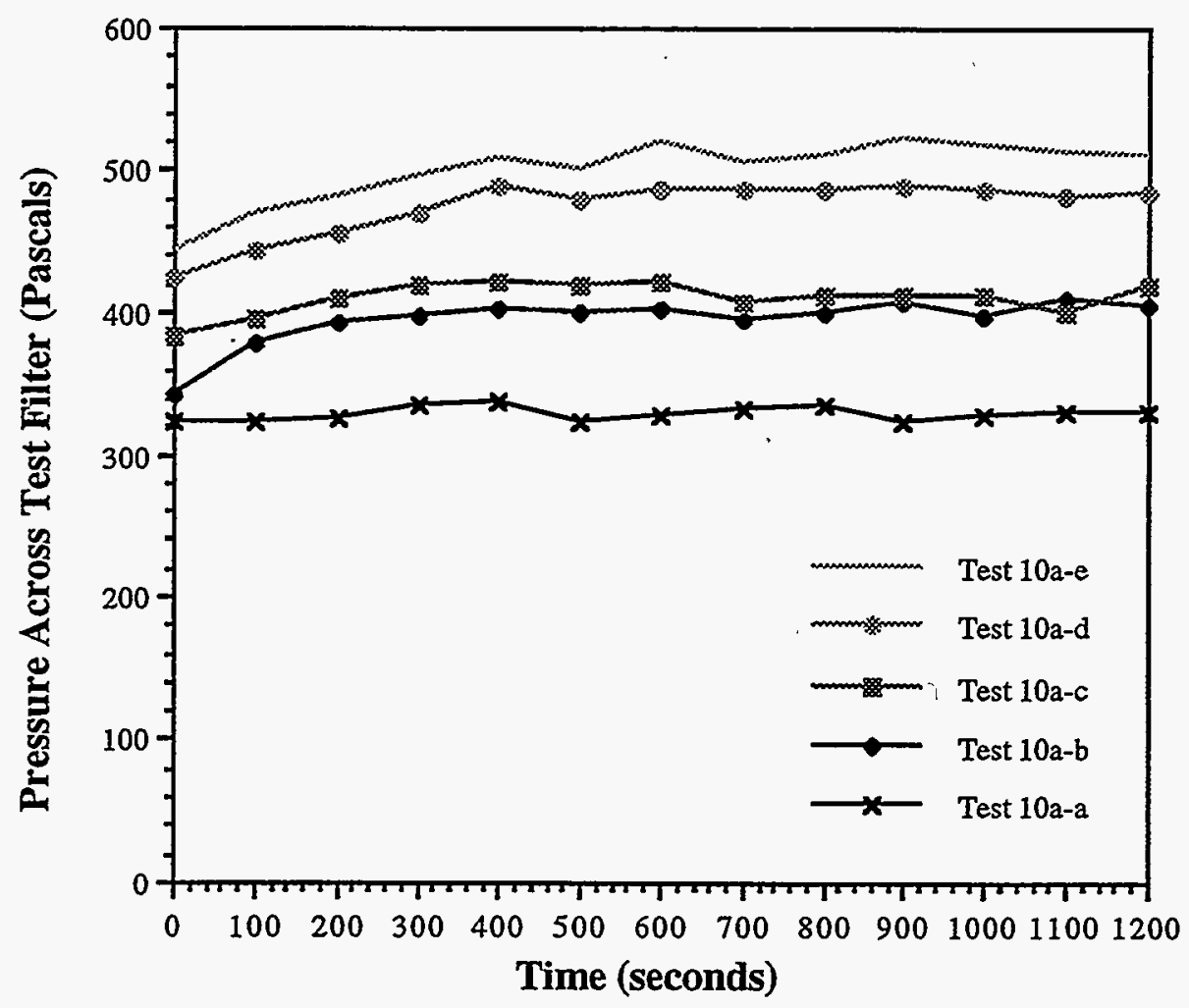

Figure 8. Plots of the pressure differential across the test filter for the breakthrough test 10 . 


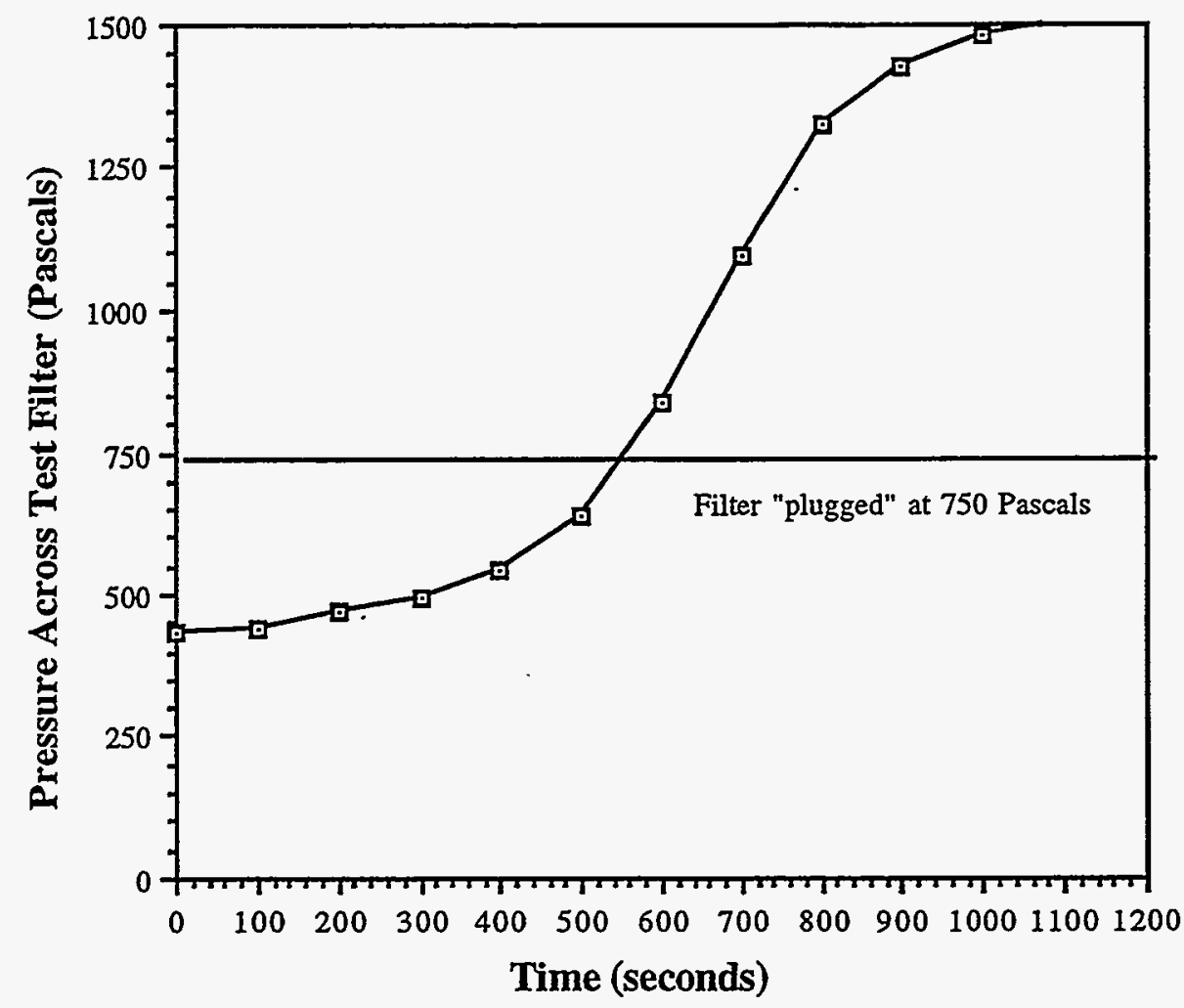

Figure 9. Plot of the pressure across filter for the breakthrough test 9e showing the plugging of the filter. 


\subsection{Preliminary HEPA Filter Data}

A single preliminary test was run with a HEPA filter in combination with an activated carbon cartridge. No detectable mass increase was measured on the downstream side of the test filter. No formaldehyde or acrolein was detected downstream of the filter during the twenty minute exposure test. Figure 10 shows a plot of the pressure difference across the test filter during sampling. The pressure across the HEPA filter/activated carbon cartridge was relatively constant throughout the test at 350 Pascals.

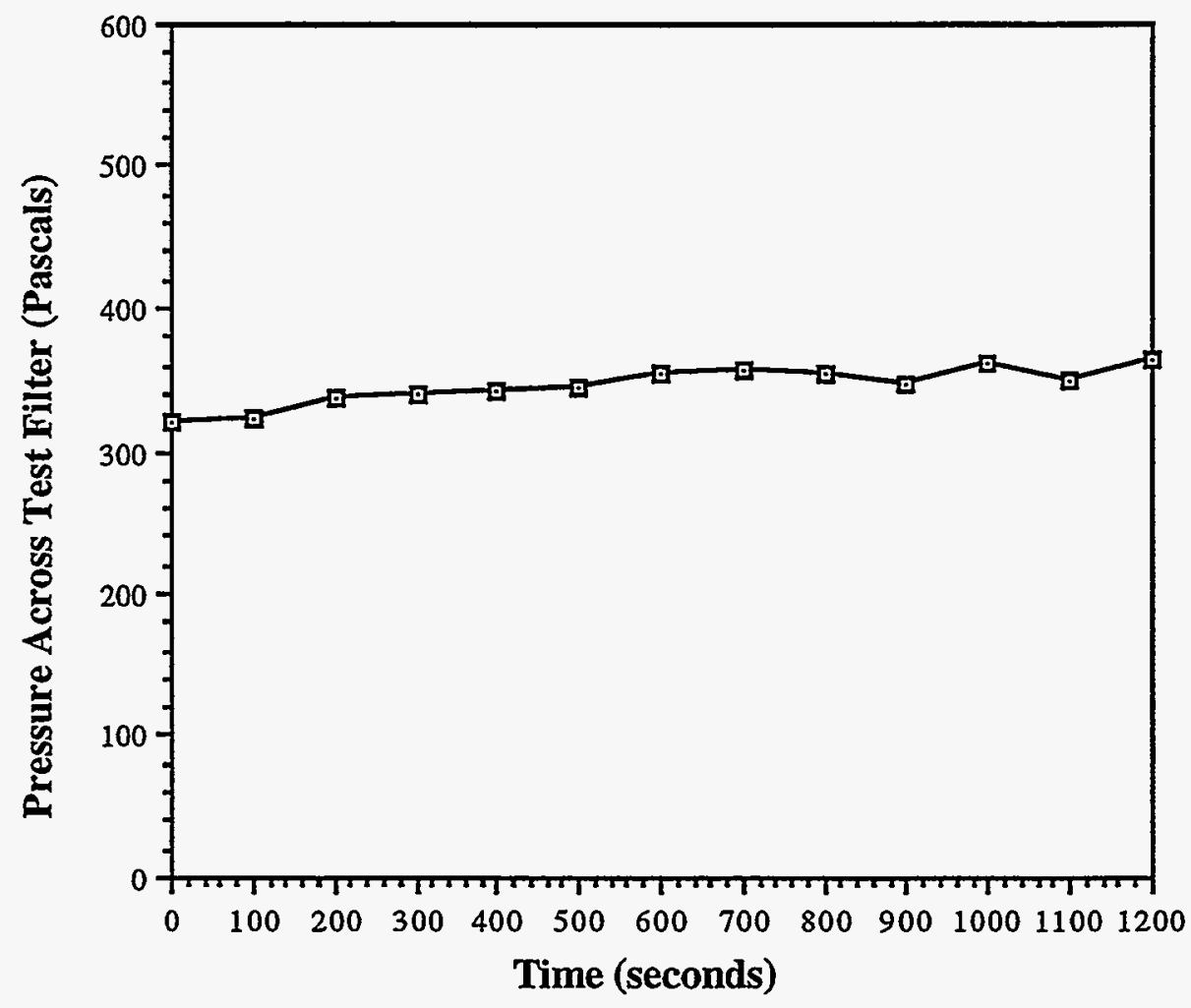

Figure 10. Plot of the pressure differential across the filter for the HEPA test. 
The experimental set up provided substantial amounts of smoke exposure. Exposure experiments were performed in a relatively short period of time and with greater reproducibility compared to previous methods. Other experiments, discussed in Appendix A, showed that methods producing lower particulate and toxic gas concentrations were less reproducible. The experimental test method used in this study is also versatile; a variety of fuel sources can be used. Preliminary tests using dry grass or hay also produced viable particulate and formaldehyde concentrations.

The concentration of particulate observed in these tests is higher than would be expected in normal wildland exposures due to the confined nature of the experiment. These concentrations represent "worst case" particulate concentrations. The accumulation of particulate on the test filters was easily observed. Even the bandannas would discolor, turning yellow across the filtration area. The bright orange electrostatic prefilters would turn brown from a single twenty minute exposure.

The Anderson impactor data shows that most of the particulate generated is 1.0-2.0 microns in diameter. This is slightly larger than the size reported by others for wildland smoke. MacArthur 28 reported particle sizes from 0.1 to 1.0 micron. The high density of the smoke and confined space of the test chamber may contribute to agglomeration of particles and raise the mean diameter of the particles. The average mass density of the challenge smoke, $2.51 \mathrm{~g} / \mathrm{m}^{3}$, is also higher than observed by others in real fire environments. This can be attributed to more dilution in the actual wildland 
environment measurements. It is difficult to consistently keep sampling probes directly in a wildland fire smoke plume. Thus, smoke density measurements are usually taken at large distances from the smoke source which allows more dilution to occur.

The formaldehyde and carbon monoxide concentrations are also higher than would be expected in actual wildland fire exposure situations. This is also due to the small amount of dilution of the smoke generated. The low temperatures observed in this study are realistic. Gas temperatures above $70^{\circ} \mathrm{C}$ cause discomfort during breathing and wildland firefighters do not work in these environments.

Any proposed wildland firefighter respiratory protection needs to be evaluated experimentally in realistic "worst case" wildland smoke conditions. Unfortunately, these conditions are difficult to quantify and reproduce. This small-scale fire may not exactly simulate a real wildland fire or wildland smoke exposure; however, it is a good approximation. Pine needles are a realistic wildland fire smoke source, and as observed in actual wildland fires 25,26 , formaldehyde, acrolein, carbon monoxide and particulate were present in the smoke produced in the test chamber. For the purposes of comparison of respiratory protection devices, it is equally important for the method to be consistent as well as realistic. The general conclusions from this study on the effectiveness of an activated carbon cartridge with prefilter compared to a bandanna with respect to penetration and breakthrough times can be directly used to evaluate performance under estimate wildland fire fighting conditions.

Comparison of the data in Table 4 and Table 5 shows that the activated carbon cartridge with prefilter is not efficient in filtering particles in the 0.7 to 1.1 micron range. 
Upstream of the activated carbon cartridge with prefilter these particles make up only 22 percent of the challenge particulate, whereas downstream of the filter, they comprise over 50 percent of the particulate. The particles in the range of 0.7 to 1.1 micron are not efficiently filtered by the human respiratory system; most of these size particles are exhaled after inhalation. $\mathrm{Yu}^{29}$ lists several references that show only 10 percent of the inhaled particles of this size are absorbed during respiration. Thus, it could be argued that these particles would not represent a respiratory threat. However, these particles have the highest probability to deposit in the sensitive alveoli of the lungs where they can do the most damage.

Particulate sampling was complicated by the presence of volatile gases in the smoke condensing on the filter paper. Freshly used filters gave off a very strong odor. Weight loss would occur well after sampling ended. This mass loss was not observed on the particulate samples downstream of the activated carbon cartridges. The error associated with weighing the volatile materials is small. Upstream samples would lose 0.009 grams after 1 week. This represents a reduction of the upstream particulate densities by only 9 percent. Correction for the additional upstream mass loss would increase the already high penetration values calculated.

In wildland smoke 25,26 , acrolein is typically found in concentrations below $1 \mathrm{ppm}$. For these tests the detection limit for acrolein was $1 \mathrm{ppm}$ as determined by calibrated standards. The flame ionization detector on the GC used for this analysis could not detect smaller concentrations of acrolein. Typically, a different type of detector is used for acrolein analysis. Little or no acrolein was detected in these tests and no acrolein data is discussed here. The method of determining formaldehyde concentration was 
inconsistent. This may be due to the problems with the GC used. During the GC analysis, large solvent shoulders frequently invalidated GC injections. After these tests, the valve controlling the flow to the column was found to be malfunctioning. It is not known if this valve is responsible for the inconsistency of the measurement.

Three of the five parameters investigated in the penetration tests appear to have no influence on the data. Comparing the penetration data of test 1 and 3, in Table 6, shows no effect of bandanna thickness on particulate penetration. The particulate penetration is the same, approximately 0.88 , for both tests. Comparison of test 1 with test 2 and test 5 with test 6 shows no influence of chamber ventilation rate. The results of test 3 and test 4 indicate that simulated respiration rate (i.e. sample rate) did not significantly effect the penetration values observed.

The other parameters investigated, type of filter and prefilter addition, did have a significant effect on particulate penetration. Comparison of the bandanna tests with the activated carbon cartridge test shows the cartridge collects particulate better than the bandanna. Comparison of test 5 and test 7 shows that the activated carbon cartridge with the electrostatic prefilter collected particulate better than the cartridge by itself. Without the prefilter, the cartridge had a particulate penetration of 45 percent. With the electrostatic prefilter, the cartridge had a particulate penetration of only 15 percent. Nevertheless, these results were disappointing. The electrostatic prefilter doesn't provide substantial particulate removal protection. A 100-fold reduction in exposure concentration is typically expected for even the simplest respirator systems. This is the minimum protection factor for firefighters recommended by Burgess 18 . Unfortunately, neither the bandanna nor the activated carbon cartridge could reduce the particulate 
exposure concentration by a factor of 100 . Because of this inefficiency, the formaldehyde sampling tubes downstream of the prefilter would visibly discolor with particulate, with the glass wool packing turning a brownish tan color. The particulate density downstream of the activated carbon cartridges with prefilter was still an order of magnitude above the TLV of diatomaceous earth.

The activated carbon cartridge formaldehyde breakthrough time of 60 minutes is adequate considering the high concentration and sampling rate used for the test. At the lower respiration rates and lower exposure concentrations expected during actual wildland fire fighting, this cartridge could provide protection for over eight hours.

Additional bandanna geometries could be evaluated that might be more realistic to actual wildland firefighter use conditions. In actual wildland fire fighting conditions, bandannas are typically wet and have been washed. The bandannas evaluated in this study were new and dry. Several test bandannas were moistened with water to evaluate the effect of water on the filtering properties. Unfortunately, the bandanna would dry out during the 20 minute sampling time. It was determined that testing wet bandannas was beyond the scope of the evaluation due to the difficulty of quantifying the drying rate. Washing the bandanna may increase its efficiency since the unwashed fibers would shrink. Thus, new bandannas may be less efficient filters than used ones. Used and wet bandannas may filter a little more particulate then the ones tested here.

A single preliminary test was run with a HEPA filter in combination with an activated carbon cartridge. This combination performed remarkably well. The HEPA filter appeared to collect all of the challenge particulate, since no detectable particulate 
mass was collected downstream. The experimental method needs to be changed in order to accurately measure the efficiency of the HEPA filter to this challenge stream. Typically, HEPA filters are 99.97 percent efficient at removing 0.3 micron particulate from airstreams. This represents a 3000 fold reduction in particulate concentration. If the HEPA filter proved to be 99.97 percent efficient in filtering this smoke particulate, this would be a 500 fold improvement in particle filtration over the electrostatic prefilter.

Because of their high efficiency, filter plugging is a problem with HEPA filters. However, Figure 10 shows there was no significant pressure build up across this HEPA filter to indicate filter plugging during the single preliminary test performed for this analysis. Repeated experiments to determine the time it takes to plug the HEPA filter should be done. The HEPA filter/activated carbon cartridge performed as well as the other activated carbon cartridges in removing formaldehyde gas from the sample stream.

Based on a single preliminary test, the HEPA filter/activated carbon cartridge may be an attractive alternative to the electrostatic prefilter combination. However, further studies are necessary in order to determine if the HEPA filter/activated carbon cartridge combination can provide adequate wildland respiratory protection. 
This thesis has described a reliable method for evaluating filter media effectiveness during exposure to wildland smoke. The test method produced a consistent and reproducible challenge smoke for 20 minutes. The challenge smoke contained high concentrations of formaldehyde, carbon monoxide and particulate. Two types of filters were thoroughly evaluated in this study: an activated carbon cartridge and a cotton bandanna. As might be expected, the cotton bandanna did not collect much formaldehyde in any of the tests. The activated carbon cartridges, on the other hand, collected all the detectable aldehydes until the cartridge became saturated. At high concentrations of smoke, the activated carbon cartridge had a breakthrough time for formaldehyde of approximately 1 hour. At slightly lower concentrations, the cartridge lasted 3 hours. Considering the high concentration and high flow rate to which the cartridge was exposed in these "worst case" tests, this is an acceptable breakthrough time. At low concentrations and flow rates, the activated carbon cartridge would be expected to last over eight hours. The activated carbon cartridge demonstrated an adequate ability to remove the chemicals of interest in this study.

Substantial amounts of particulate material penetrated and passed through both filters. The activated carbon cartridge with the prefilter collected more particulate than the cotton bandanna. Nevertheless, the prefilter did not do a very efficient job of filtering this particulate. The activated carbon cartridge with prefilter filtered out only 85 percent of the challenge particulate. Thus, 15 percent of the particulate was passing through the filter and potentially into the lungs of a respirator user. 
From these tests, it is unclear that this activated carbon cartridge and prefilter is a significant improvement over the bandanna. If the elimination or reduction of chemical exposure is a high priority, then activated carbon cartridges represent a significant improvement in respiratory protection. If, however, the elimination of particulate exposure is the highest priority, then it is an improvement but not a significant one. Considering the added restriction associated with cartridge use during fire fighting, it probably is not a practical particulate respiratory protection solution.

The HEPA type filter warrants further testing based on the excellent initial results observed. The combination of HEPA filter and activated carbon cartridge could provide superior wildland firefighter respiratory protection. The activated carbon cartridge has already demonstrated in these tests that it effectively removes formaldehyde from a typical challenge stream and the HEPA filter has the ability to filter high concentrations of particulate very efficiently. However, the longevity of the HEPA filter/activated carbon cartridge combination still needs to be evaluated. Breakthrough tests need to be done with the HEPA filter to evaluate whether filter plugging will occur with longer exposures to wildland smoke. 


\section{References}

1. "The Effects of Forest Fire Smoke on Fire Fighters: A Comprehensive Study Plan.", D. Ward et al., John Hopkins University (1989).

2. "The Most Difficult Season in History.", Wilson J.F., Fire Command, 56:14-18 (1989).

3. "U.S. Fire Fighters Injuries - 1988.", Karter M.J. et al., Fire Command, 56:20-29 (1989).

4. "Pulmonary Function and Respiratory Symptoms in Wildland Firefighters.", Rothman, N., et al., J. Occup. Med., 33(11):1163-1167 (1991).

5. "U.S. Fire Fighter Injuries - 1990.", Karter M.J. et al., NFPA Journal, Nov/Dec, 43-53 (1991).

6. "Analysis of Condensates from Wood Smoke: Components Derived from Polysaccharides and Lignins.", Edye, L.A. and Richards, G.N., Environmental Science and Technology, 25:1133-1137 (1991).

7. "Polynuclear Aromatic Hydrocarbons in Forest Fire Smoke.", McMahon, C.K. et al., Carcinogenesis, 3:140-145 (1978).

8. "Toxic Gases from Fires.", Terrill J.B., et al., Science, 200:1343-1347 (1978).

9. "Sensory Irritation and Incapacitation Evoked by Thermal Decomposition Products of Polymers and Comparisons with Known Sensory Irritants.", Barrow, C.S. et al., Arch. Environ. Health, 33:79-88 (1978).

10. "Documentation of the Threshold Limit Values and Biological Exposure Indices.", American Conference of Governmental Industrial Hygienists Inc., 5th Edition (1986).

11. "Toxic Products from Fires.", Hartzell, G.E., et al., Am. Ind. Hyg. Assoc. J., 44(4):248-255 (1983).

12. "Air Contaminants - Permissible Exposure Limits.", Title 29 Code of Federal Regulations Part 1910.1000, U.S. Department of Labor, Occupational Safety and Health Administration, OSHA 3112, (1989).

13. "1993-1994 Threshold Limit Values for Chemical Substances and Physical Agents and Biological Exposure Indices.", American Conference of Governmental Industrial Hygienists Inc., ISBN 1-88247-03-8 (1993).

14. "The Effect of the Sensory Irritant Component of a Combustion Atmosphere Derived from Douglas Fir on the Leg-flexion Avoidance Response of the Rat.", Farrar D. G., J. Combustion Toxicology, 7(1):3-22 (1980). 


\section{References (cont.)}

15. "Advances in the Characterization and Control of Emissions from Prescribed Broadcast Fires of Coniferous Species Logging Slash on Clear-cut Units.", Ward, D.E. and C.C. Hardy, Pacific Northwest Research Station USDA Forest Service, (1986).

16. "Large-loss Fires in the United States during 1988 - A year of historical losses.", Taylor K.T. and Tremblay K., Fire J., 83:58-63 (1989).

17. "A Year for the Books: Large-loss Fires in the United States during 1989.", Taylor, K.T. and Tremblay, K., Fire J., 84:44-49 (1990).

18. "Minimum Protection Factors for Respiratory Protective Devices for Firefighters.", Burgess, W.A. et al., Am. Ind. Hyg. Assoc. J., 38(1):18-23 (1977).

19. "Air Contaminates Encountered by Firefighters.", Treitman, R.D. et al., Am. Ind. Hyg. Assoc. J., 41(11):796-802 (1980).

20. "Exposure of Firefighters to Toxic Air Contaminants.", Gold, A. et al., Am. Ind. Hyg. Assoc. J., 39(7):534-539 (1978).

21. "Consideration of Acute Toxicological Responses to Components of Vegetation Smoke.", Dost, F., Draft Report Bureau of Land Management, November (1986).

22. "A Preliminary Analysis of Employee Exposure to Carbon Monoxide on Wildfires and Prescribed Burns.", Jackson G., et al., USDA Forest Service, EDT 2424 (1979).

23. "Yellowstone National Park Fire Exposures 1988.", NIOSH PB-20895 (1990).

24. "Fire Fighters' Exposure to Carbon Monoxide During Australian Bushfires.", Brotherhood et al., Am. Ind. Hyg. Assoc. J., 51(4):234-240 (1990).

25. "Fire Fighter Smoke Exposure at Prescribed Burns: A study and action recommendation.", Reinhardt, T.E., USDA Forest Service (1990).

26. "Occupational Exposures in California Wildland Fire Fighting.", Matera, B.L., et al.,Am. Ind. Hyg. Assoc. J., 53(1):69-76 (1992).

27. "Fundamental Factors in the Design of Protective Respiratory Equipment.", Silverman, L. et al., Dept. of Physiology and Industrial Hygiene, Harvard School of Public Health, PB-28613, (1943).

28. "Particle Sizes in Bushfire Smoke.", MacArthur, D.A., Aust. For., 30:274-278 (1966).

29. "A Comparative Study of Aerosol Deposition in Different Lung Models.", Yu, C.P. and Diu, C.K., Am. Ind. Hyg. Assoc. J., 43(1):54-85 (1982). 
Appendixes 


\section{Appendix A. \\ Discussion of Other Test Geometries}

The test method presented in the body of the report was developed after several attempts to use douglas fir sticks as a fuel source. Eventually, douglas fir sticks were abandoned

for pine needles which produced a thick and consistent smoke during slow combustion. Many problems occurred with douglas fir. Either the fire burned too fast or it extinguished completely. In most cases, very little smoke was produced from douglas fir sticks. In none of the douglas fir tests was it possible to measure any significant particulate mass. Douglas fir simply burned too efficiently. Additionally, very little aldehyde was detected in the ORBO-24 sampling tubes. A variety of douglas fir stick configurations were tried from tightly packed to thinly packed cribs of wood. A few unsuccessful tests were attempted where the sticks were moistened to inhibit combustion. Radiant heat sources were used to help maintain combustion at a slow rate to produce a smoldering fire. Several other geometries of burning hay and pine needles were also attempted. Wrapping the hay and pine needles into small or large bundles did not produce usable smoke. Whether the bundles were vertically or horizontally oriented didn't improve the combustion properties of the bundled fuel. 
Appendix B

Tables of Experimental Data 
Appendix B-1.

Mass Loss Data.

$\begin{array}{lccccc} & \begin{array}{c}\text { Average } \\ \text { Mass } \\ \text { from } \\ \text { 0-300 sec } \\ \text { (grams) }\end{array} & \begin{array}{c}\text { Average } \\ \text { Mass } \\ \text { from } \\ \begin{array}{c}300-600 \text { sec } \\ \text { (grams) }\end{array}\end{array} & \begin{array}{c}\text { Average } \\ \text { Mass } \\ \text { from } \\ \text { 600-900 sec } \\ \text { (grams) }\end{array} & \begin{array}{c}\text { Average } \\ \text { Mass } \\ \text { from } \\ 900-1200 \text { sec } \\ \text { (grams) }\end{array} & \begin{array}{c}\text { Maximum } \\ \text { Observed } \\ \text { Mass }\end{array} \\ \text { (grams) }\end{array}$


Appendix B-1 (cont.).

Mass Loss Data.

\begin{tabular}{|c|c|c|c|c|c|c|c|}
\hline $\begin{array}{l}\text { Initial } \\
\text { Mass }\end{array}$ & $\begin{array}{l}\text { Final } \\
\text { Mass }\end{array}$ & $\begin{array}{c}\text { Total } \\
\text { Mass } \\
\text { Loss } \\
\text { during } \\
\text { Test }\end{array}$ & $\begin{array}{c}\text { Mass } \\
\text { at start } \\
\text { of } \\
\text { Sampling }\end{array}$ & $\begin{array}{l}\text { Mass } \\
\text { at end } \\
\text { of } \\
\text { Sampling }\end{array}$ & $\begin{array}{c}\text { Total } \\
\text { Mass } \\
\text { Loss } \\
\text { during } \\
\text { Sampling }\end{array}$ & $\begin{array}{c}\text { Average } \\
\text { Rate of } \\
\text { Mass } \\
\text { Loss } \\
\text { during } \\
\text { Sampling }\end{array}$ & $\begin{array}{c}\text { Percent } \\
\text { Mass } \\
\text { Loss } \\
\text { during } \\
\text { Sampling }\end{array}$ \\
\hline$-m$ & & mo & (grams) & (grams) & (grams & min. & \\
\hline
\end{tabular}

\begin{tabular}{|c|c|c|c|c|c|c|c|c|}
\hline $\begin{array}{l}\text { Test } 1 \\
\text { Test 2a } \\
\text { Test 2b } \\
\text { Test 3a } \\
\text { Test 3b } \\
\text { Test 4 } \\
\text { Test 5 } \\
\text { Test } 6 \\
\text { Test 7a } \\
\text { Test 7b } \\
\text { Test 7c } \\
\text { Test } 8\end{array}$ & $\begin{array}{l}237 \\
240 \\
259 \\
237 \\
263 \\
242 \\
226 \\
230 \\
235 \\
249 \\
248 \\
222\end{array}$ & $\begin{array}{l}51 \\
49 \\
79 \\
53 \\
79 \\
57 \\
40 \\
43 \\
51 \\
64 \\
63 \\
45\end{array}$ & $\begin{array}{l}186 \\
191 \\
180 \\
185 \\
184 \\
185 \\
186 \\
187 \\
185 \\
185 \\
185 \\
177\end{array}$ & $\begin{array}{l}231 \\
236 \\
253 \\
223 \\
260 \\
220 \\
220 \\
218 \\
227 \\
245 \\
234 \\
216\end{array}$ & $\begin{array}{c}113 \\
116 \\
154 \\
88 \\
142 \\
91 \\
87 \\
100 \\
97 \\
114 \\
106 \\
101\end{array}$ & $\begin{array}{l}118 \\
120 \\
98 \\
135 \\
118 \\
129 \\
133 \\
118 \\
130 \\
131 \\
128 \\
115\end{array}$ & $\begin{array}{l}5.9 \\
6.0 \\
4.9 \\
6.7 \\
5.9 \\
6.4 \\
6.6 \\
5.9 \\
6.5 \\
6.5 \\
6.4 \\
5.8\end{array}$ & $\begin{array}{l}63 \% \\
63 \% \\
54 \% \\
73 \% \\
64 \% \\
70 \% \\
71 \% \\
63 \% \\
70 \% \\
71 \% \\
70 \% \\
65 \%\end{array}$ \\
\hline $\begin{array}{l}\text { Test 9a } \\
\text { Test 9b da } \\
\text { Test 9c da } \\
\text { Test 9d da } \\
\text { Test 9e }\end{array}$ & $\begin{array}{l}246 \\
\text { lata lost } \\
\text { lata lost } \\
\text { lata lost } \\
236\end{array}$ & $\begin{array}{c}61 \\
\text { data lo } \\
\text { data lo } \\
\text { data lo } \\
57\end{array}$ & $\begin{array}{l}185 \\
\text { data lost } \\
\text { data lost } \\
\text { data lost } \\
179\end{array}$ & $\begin{array}{c}239 \\
\text { data lost } \\
\text { data lost } \\
\text { data lost } \\
223\end{array}$ & $\begin{array}{c}110 \\
\text { data lost } \\
\text { data lost } \\
\text { data lost } \\
106\end{array}$ & $\begin{array}{c}130 \\
\text { data lost } \\
\text { data lost } \\
\text { data lost } \\
118\end{array}$ & $\begin{array}{c}6.5 \\
\text { data lost } \\
\text { data lost } \\
\text { data lost } \\
5.9\end{array}$ & $\begin{array}{c}70 \% \\
\text { data lost } \\
\text { data lost } \\
\text { data lost } \\
66 \%\end{array}$ \\
\hline $\begin{array}{l}\text { Test } 10 \mathrm{a}-\mathrm{a}^{*} \\
\text { Test } 10 \mathrm{a}-\mathrm{b}^{*} \\
\text { Test } 10 \mathrm{a}-\mathrm{c}^{*} \\
\text { Test } 10 \mathrm{a}-\mathrm{d}^{*} \\
\text { Test } 10 \mathrm{a}-\mathrm{e}^{*} \\
\text { Test } 10 \mathrm{~b}-\mathrm{a}^{*} \\
\text { Test } 10 \mathrm{~b}-\mathrm{b}^{*} \\
\text { Test } 10 \mathrm{~b}-\mathrm{c}^{*} \\
\text { Test } 10 \mathrm{c}-\mathrm{a}^{*} \\
\text { Test } 10 \mathrm{c}-\mathrm{b}^{*} \\
\text { Test } \mathrm{c}^{*}\end{array}$ & 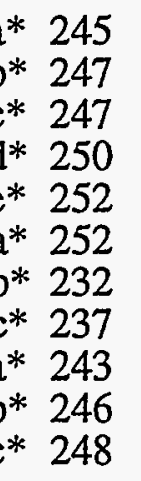 & $\begin{array}{c}95 \\
98 \\
116 \\
105 \\
123 \\
116 \\
78 \\
101 \\
59 \\
89 \\
60\end{array}$ & $\begin{array}{l}150 \\
149 \\
132 \\
146 \\
130 \\
137 \\
154 \\
137 \\
184 \\
157 \\
189\end{array}$ & $\begin{array}{l}233 \\
235 \\
243 \\
247 \\
248 \\
237 \\
217 \\
227 \\
239 \\
237 \\
242\end{array}$ & $\begin{array}{l}112 \\
111 \\
127 \\
119 \\
134 \\
161 \\
82 \\
102 \\
94 \\
99 \\
108\end{array}$ & $\begin{array}{l}120 \\
124 \\
116 \\
128 \\
114 \\
76 \\
135 \\
125 \\
145 \\
137 \\
134\end{array}$ & $\begin{array}{l}6.0 \\
6.2 \\
5.8 \\
6.4 \\
5.7 \\
3.8 \\
6.7 \\
6.2 \\
7.2 \\
6.9 \\
6.7\end{array}$ & $\begin{array}{l}80 \% \\
83 \% \\
88 \% \\
88 \% \\
88 \% \\
56 \% \\
87 \% \\
91 \% \\
79 \% \\
87 \% \\
71 \%\end{array}$ \\
\hline Test 11 & 235 & 53 & 182 & 229 & 96 & 132 & 6.6 & $72 \%$ \\
\hline \multicolumn{6}{|c|}{ * Test interrupted } & Std. & $\begin{array}{l}6.2 \\
0.7\end{array}$ & $11 \%$ \\
\hline
\end{tabular}


Appendix B-2.

Carbon Monoxide Data.

\begin{tabular}{|c|c|c|c|c|c|}
\hline & $\begin{array}{l}\text { Average } \\
\text { Carbon } \\
\text { Monoxide } \\
\text { concentration } \\
\text { from } \\
0-300 \mathrm{sec} \\
\text { (ppm) }\end{array}$ & $\begin{array}{l}\text { Average } \\
\text { Carbon } \\
\text { Monoxide } \\
\text { concentration } \\
\text { from } \\
300-600 \mathrm{sec} \\
\text { (ppm) }\end{array}$ & $\begin{array}{c}\text { Average } \\
\text { Carbon } \\
\text { Monoxide } \\
\text { concentration } \\
\text { from } \\
600-900 \mathrm{sec} \\
\text { (ppm) }\end{array}$ & $\begin{array}{c}\text { Average } \\
\text { Carbon } \\
\text { Monoxide } \\
\text { concentration } \\
\text { from } \\
900-1200 \mathrm{sec} \\
\text { (ppm) }\end{array}$ & $\begin{array}{l}\text { Maximum } \\
\text { Observed } \\
\text { Carbon } \\
\text { Monoxide } \\
\text { concentration } \\
\text { (ppm) }\end{array}$ \\
\hline $\begin{array}{l}\text { Test } 1 \\
\text { Test } 2 \mathrm{a} \\
\text { Test } 2 \mathrm{~b} \\
\text { Test } 3 \mathrm{a} \\
\text { Test } 3 \mathrm{~b} \\
\text { Test } 4 \\
\text { Test } 5 \\
\text { Test } 6 \\
\text { Test } 7 \mathrm{a} \\
\text { Test } 7 \mathrm{~b} \\
\text { Test } 7 \mathrm{c} \\
\text { Test } 8\end{array}$ & $\begin{array}{c}858 \\
847 \\
1319 \\
1379 \\
242 \\
1959 \\
1218 \\
2208 \\
1436 \\
1279 \\
1727 \\
1116\end{array}$ & $\begin{array}{l}1470 \\
1725 \\
1372 \\
1453 \\
1368 \\
1804 \\
1928 \\
2327 \\
1735 \\
1748 \\
1633 \\
1946\end{array}$ & $\begin{array}{l}1544 \\
1892 \\
1155 \\
1693 \\
1452 \\
1310 \\
1543 \\
1832 \\
1445 \\
1377 \\
1169 \\
1717\end{array}$ & $\begin{array}{c}932 \\
1805 \\
912 \\
1466 \\
1040 \\
1283 \\
943 \\
1506 \\
1190 \\
981 \\
985 \\
1125\end{array}$ & $\begin{array}{l}1971 \\
2122 \\
1677 \\
1947 \\
1805 \\
2175 \\
2128 \\
2543 \\
2147 \\
2043 \\
2172 \\
2040\end{array}$ \\
\hline $\begin{array}{l}\text { Test 9-a } \\
\text { Test 9-b } \\
\text { Test 9-c } \\
\text { Test 9-d } \\
\text { Test } 9-\mathrm{e}\end{array}$ & $\begin{array}{c}1514 \\
\text { data lost } \\
\text { data lost } \\
\text { data lost } \\
2197\end{array}$ & $\begin{array}{c}2142 \\
\text { data lost } \\
\text { data lost } \\
\text { data lost } \\
2306\end{array}$ & $\begin{array}{c}1823 \\
\text { data lost } \\
\text { data lost } \\
\text { data lost } \\
2247\end{array}$ & $\begin{array}{c}1080 \\
\text { data lost } \\
\text { data lost } \\
\text { data lost } \\
1808\end{array}$ & $\begin{array}{c}2285 \\
\text { data lost } \\
\text { data lost } \\
\text { data lost } \\
2467\end{array}$ \\
\hline $\begin{array}{l}\text { Test } 10 \mathrm{a}-\mathrm{a} \\
\text { Test } 10 \mathrm{a}-\mathrm{b} \\
\text { Test } 10 \mathrm{a}-\mathrm{c} \\
\text { Test } 10 \mathrm{a}-\mathrm{d} \\
\text { Test } 10 \mathrm{a}-\mathrm{e} \\
\text { Test } 10 \mathrm{~b}-\mathrm{a} \\
\text { Test } 10 \mathrm{~b}-\mathrm{b} \\
\text { Test } 10 \mathrm{~b}-\mathrm{c} \\
\text { Test } 10 \mathrm{c}-\mathrm{a} \\
\text { Test } 10 \mathrm{c}-\mathrm{b} \\
\text { Test } 10 \mathrm{c}-\mathrm{c}\end{array}$ & $\begin{array}{l}1984 \\
1753 \\
1205 \\
1329 \\
1339 \\
1328 \\
2428 \\
1768 \\
1449 \\
1602 \\
1205\end{array}$ & $\begin{array}{l}1797 \\
1514 \\
1442 \\
1666 \\
1929 \\
875 \\
2637 \\
1588 \\
2363 \\
2050 \\
1296\end{array}$ & $\begin{array}{c}1509 \\
1418 \\
1692 \\
1246 \\
1622 \\
766 \\
2144 \\
1994 \\
2192 \\
1968 \\
1257\end{array}$ & $\begin{array}{l}1611 \\
2213 \\
1336 \\
1538 \\
962 \\
895 \\
1337 \\
1854 \\
1581 \\
1300 \\
1788\end{array}$ & $\begin{array}{l}2264 \\
2371 \\
1856 \\
2039 \\
2103 \\
1689 \\
2757 \\
2477 \\
2523 \\
2236 \\
1942\end{array}$ \\
\hline Test 11 & 1591 & 2226 & $\begin{array}{l}\text { verall Averag } \\
\text { Std. Dev. }\end{array}$ & $\begin{array}{l}1531 \\
267\end{array}$ & 2370 \\
\hline
\end{tabular}


Appendix B-3. Formaldehyde Oxazolidine Sampling Data.

\begin{tabular}{|c|c|c|c|c|c|c|}
\hline & $\begin{array}{l}\text { Retention } \\
\text { time } \\
\text { (min) }\end{array}$ & $\begin{array}{l}\text { Upstream } \\
\text { area } \\
\text { counts }\end{array}$ & $\begin{array}{l}\text { Average } \\
\text { area } \\
\text { counts }\end{array}$ & $\begin{array}{l}\text { Retention } \\
\text { time }\end{array}$ & $\begin{array}{l}\text { Downstream } \\
\text { area } \\
\text { counts }\end{array}$ & $\begin{array}{c}\text { Average } \\
\text { area } \\
\text { counts }\end{array}$ \\
\hline Test 1 & $\begin{array}{l}9.15 \\
9.13 \\
9.12\end{array}$ & $\begin{array}{l}33,561 \\
39,728 \\
46,772\end{array}$ & 40,020 & $\begin{array}{l}9.12 \\
9.12 \\
9.13\end{array}$ & $\begin{array}{l}37,389 \\
34,394 \\
33,092\end{array}$ & 34,958 \\
\hline Test 2a & $\begin{array}{l}9.12 \\
9.11 \\
9.12\end{array}$ & $\begin{array}{l}35,023 \\
48,086 \\
55,250\end{array}$ & 46,120 & $\begin{array}{l}9.17 \\
9.16 \\
9.15\end{array}$ & $\begin{array}{l}33,381 \\
39,484 \\
49,755\end{array}$ & 34,469 \\
\hline Test2b & $\begin{array}{l}9.10 \\
9.11 \\
9.11\end{array}$ & $\begin{array}{l}38,421 \\
28,830 \\
34,819\end{array}$ & 34,023 & $\begin{array}{l}9.10 \\
9.10 \\
9.13\end{array}$ & $\begin{array}{l}19,649 \\
30,075 \\
24,330\end{array}$ & 24,023 \\
\hline Test $3 a$ & $\begin{array}{l}9.11 \\
9.12 \\
9.11\end{array}$ & $\begin{array}{l}34,484 \\
47,046 \\
36,457\end{array}$ & 39,329 & $\begin{array}{l}9.13 \\
9.11 \\
9.13\end{array}$ & $\begin{array}{l}27,069 \\
34,422 \\
28,834\end{array}$ & 30,108 \\
\hline Test $3 b$ & $\begin{array}{l}9.11 \\
9.10 \\
9.10\end{array}$ & $\begin{array}{l}31,115 \\
33,215 \\
33,510\end{array}$ & 32,612 & $\begin{array}{l}9.10 \\
9.10 \\
9.10\end{array}$ & $\begin{array}{l}30,248 \\
26,255 \\
21,670\end{array}$ & 26,058 \\
\hline Test 4 & $\begin{array}{l}9.14 \\
9.28 \\
9.14\end{array}$ & $\begin{array}{l}19,899 \\
16,303 \\
32,908\end{array}$ & 23,037 & $\begin{array}{l}9.15 \\
9.16 \\
9.15\end{array}$ & $\begin{array}{l}25,787 \\
37,420 \\
17,120\end{array}$ & 26,776 \\
\hline Test 5 & $\begin{array}{l}9.14 \\
9.13 \\
9.15\end{array}$ & $\begin{array}{l}23,310 \\
28,770 \\
28,436\end{array}$ & 26,839 & & $\begin{array}{l}\text { Not Detected } \\
\text { Not Detected } \\
\text { Not Detected }\end{array}$ & \\
\hline Test 6 & $\begin{array}{l}9.12 \\
9.12 \\
9.13\end{array}$ & $\begin{array}{l}33,576 \\
38,076 \\
45,137\end{array}$ & 38,930 & & $\begin{array}{l}\text { Not Detected } \\
\text { Not Detected } \\
\text { Not Detected }\end{array}$ & \\
\hline Test $7 \mathrm{a}$ & $\begin{array}{l}9.17 \\
9.15 \\
9.16\end{array}$ & $\begin{array}{l}28,510 \\
36,134 \\
41,546\end{array}$ & 35,397 & & $\begin{array}{l}\text { Not Detected } \\
\text { Not Detected } \\
\text { Not Detected }\end{array}$ & \\
\hline Test $7 \mathrm{~b}$ & $\begin{array}{l}9.16 \\
9.17 \\
9.16\end{array}$ & $\begin{array}{l}13,902 \\
15,531 \\
20,519\end{array}$ & 17,211 & & $\begin{array}{l}\text { Not Detected } \\
\text { Not Detected } \\
\text { Not Detected }\end{array}$ & \\
\hline Test $7 \mathrm{c}$ & $\begin{array}{l}9.15 \\
9.16 \\
9.17\end{array}$ & $\begin{array}{l}44,265 \\
42,869 \\
34,561\end{array}$ & 40,565 & & $\begin{array}{l}\text { Not Detected } \\
\text { Not Detected } \\
\text { Not Detected }\end{array}$ & \\
\hline
\end{tabular}




\section{Appendix B-3 (cont.). Formaldehyde Oxazolidine Sampling Data.}

\begin{tabular}{|c|c|c|c|c|c|c|}
\hline & $\begin{array}{l}\text { Retention } \\
\text { time } \\
(\mathrm{min})\end{array}$ & $\begin{array}{l}\text { Upstream } \\
\text { area } \\
\text { counts }\end{array}$ & $\begin{array}{l}\text { Average } \\
\text { area } \\
\text { counts }\end{array}$ & $\begin{array}{l}\text { Retention } \\
\text { time }\end{array}$ & $\begin{array}{c}\text { Downstream } \\
\text { area } \\
\text { counts }\end{array}$ & $\begin{array}{c}\text { Average } \\
\text { area } \\
\text { counts }\end{array}$ \\
\hline Test 8 & $\begin{array}{l}9.12 \\
9.13 \\
9.13\end{array}$ & $\begin{array}{l}23,828 \\
33,410 \\
35,773\end{array}$ & 31,004 & & $\begin{array}{l}\text { Not Detected } \\
\text { Not Detected } \\
\text { Not Detected }\end{array}$ & \\
\hline $\begin{array}{l}\text { Test 9-a } \\
\text { Test 9-b } \\
\text { Test 9-c } \\
\text { Test 9-d }\end{array}$ & $\begin{array}{l}9.15 \\
9.14 \\
9.14 \\
9.14\end{array}$ & $\begin{array}{l}30,273 \\
33,408 \\
45,087 \\
58,412\end{array}$ & 40,196 & & $\begin{array}{l}\text { Not Detected } \\
\text { Not Detected } \\
\text { Not Detected } \\
\text { Not Detected }\end{array}$ & \\
\hline Test 9-e & 9.15 & 33,802 & & $\begin{array}{l}9.12 \\
9.11 \\
9.10\end{array}$ & $\begin{array}{l}13,377 \\
14,987 \\
18,645\end{array}$ & 15,670 \\
\hline $\begin{array}{l}\text { Test } 10 \mathrm{a}-\mathrm{a} \\
\text { Test } 10 \mathrm{a}-\mathrm{b} \\
\text { Test } 10 \mathrm{a}-\mathrm{c} \\
\text { Test } 10 \mathrm{a}-\mathrm{d}\end{array}$ & $\begin{array}{l}9.16 \\
9.16 \\
9.16 \\
9.16\end{array}$ & $\begin{array}{l}32,551 \\
42,939 \\
37,734 \\
46,140\end{array}$ & 39,841 & & $\begin{array}{c}\text { Not Detected } \\
\text { Not Detected } \\
\text { Not Detected } \\
16.179\end{array}$ & \\
\hline Test 10a-e & 9.15 & 39,750 & & $\begin{array}{l}9.12 \\
9.11 \\
9.12 \\
9.12\end{array}$ & $\begin{array}{l}10,179 \\
17,593 \\
26,456 \\
40,135\end{array}$ & 33,296 \\
\hline $\begin{array}{l}\text { Test } 10 \mathrm{~b}-\mathrm{a} \\
\text { Test } 10 \mathrm{~b}-\mathrm{b} \\
\text { Test } 10 \mathrm{~b}-\mathrm{c}\end{array}$ & $\begin{array}{l}9.11 \\
9.12 \\
9.15\end{array}$ & $\begin{array}{l}43,653 \\
33,595 \\
36,450\end{array}$ & 37,899 & $\begin{array}{l}9.12 \\
9.12 \\
9.12 \\
9.12 \\
9.12\end{array}$ & $\begin{array}{c}\text { Not Detected } \\
\text { Not Detected } \\
5,882 \\
2,448 \\
2,519 \\
9,288 \\
6,882\end{array}$ & 5,404 \\
\hline $\begin{array}{l}\text { Test } 10 \mathrm{c}-\mathrm{a} \\
\text { Test } 10 \mathrm{c}-\mathrm{b} \\
\text { Test } 10 \mathrm{c}-\mathrm{c}\end{array}$ & $\begin{array}{l}9.10 \\
9.10 \\
9.10\end{array}$ & $\begin{array}{l}34,294 \\
39,403 \\
34,278\end{array}$ & 35,992 & $\begin{array}{l}9.11 \\
9.11 \\
9.11\end{array}$ & $\begin{array}{c}\text { Not Detected } \\
\text { Not Detected } \\
17,779 \\
27,816 \\
20,011\end{array}$ & 21,869 \\
\hline Test 11 & \multicolumn{3}{|c|}{$\begin{array}{l}\text { No sampling done } \\
\text { No sampling done } \\
\text { No sampling done }\end{array}$} & & $\begin{array}{l}\text { Not Detected } \\
\text { Not Detected } \\
\text { Not Detected }\end{array}$ & \\
\hline
\end{tabular}


Appendix B-4.

Gas temperature data collected at the bottom of the test chamber.

\begin{tabular}{|c|c|c|c|c|c|c|}
\hline & & Average & Average & Average & Average & Maximum \\
\hline & Initial & Temperatur & Temperature & Temperature & Temperature & Observed \\
\hline & emperature & from & from & from & from & Temperat \\
\hline & & $0-300 \mathrm{sec}$ & $300-600 \mathrm{sec}$ & $600-900 \mathrm{sec}$ & $900-1200 \mathrm{sec}$ & \\
\hline & $\left({ }^{\circ} \mathrm{C}\right)$ & $\left({ }^{\circ} \mathrm{C}\right)$ & $\left({ }^{\circ} \mathrm{C}\right)$ & $\left({ }^{\circ} \mathrm{C}\right)$ & $\left({ }^{\circ} \mathrm{C}\right)$ & $\left({ }^{\circ} \mathrm{C}\right)$ \\
\hline Test 1 & 25.3 & 28.7 & 28.5 & 29.2 & 29.7 & 32.7 \\
\hline Test $2 a$ & 25.8 & 29.3 & 29.6 & 30.0 & 30.7 & 32.2 \\
\hline Test $2 \mathrm{~b}$ & 25.5 & 27.2 & 27.4 & 28.0 & 28.3 & 33.1 \\
\hline Test $3 \mathrm{a}$ & 24.2 & 26.4 & 26.8 & 27.4 & 28.1 & 31.5 \\
\hline Test $3 b$ & 27.7 & 30.9 & 31.9 & 31.9 & 32.5 & 34.0 \\
\hline Test 4 & 27.2 & 30.5 & 31.7 & 32.0 & 32.5 & 34.2 \\
\hline Test 5 & 24.6 & 27.1 & 27.3 & 28.0 & 28.6 & 31.9 \\
\hline Test 6 & 25.0 & 27.8 & 28.5 & 29.2 & 29.7 & 31.3 \\
\hline Test $7 \mathrm{a}$ & 27.1 & 30.0 & 30.1 & 30.6 & 31.1 & 33.5 \\
\hline Test $7 \mathrm{~b}$ & 24.7 & 27.2 & 27.5 & 28.3 & 28.9 & 31.5 \\
\hline Test 7c & 23.7 & 26.3 & 27.5 & 27.5 & 28.2 & 30.8 \\
\hline Test 8 & 20.7 & 24.2 & 24.3 & 25.0 & 25.6 & 27.9 \\
\hline Test 9-a & 26.6 & 28.7 & 29.4 & 30.2 & 30.4 & 33.2 \\
\hline Test 9-b & data lost & data lost & data lost & data lost & data lost & data lost \\
\hline Test 9-c & data lost & data lost & data lost & data lost & data lost & data lost \\
\hline Test 9-d & data lost & data lost & data lost & data lost & data lost & data lost \\
\hline Test 9-e & 21.3 & 22.6 & 23.3 & 23.6 & 24.5 & 29.6 \\
\hline Test $10 \mathrm{a}-$ & -a 23.6 & 25.0 & 25.4 & 25.8 & 26.9 & 29.4 \\
\hline Test $10 \mathrm{a}-$ & -b 26.0 & 28.4 & 28.7 & 29.0 & 30.2 & 31.6 \\
\hline Test $10 \mathrm{a}-$ & -c 26.6 & 29.8 & 30.0 & 30.6 & 31.3 & 32.3 \\
\hline Test $10 \mathrm{a}-$ & -d 28.0 & 31.4 & 31.4 & 31.7 & 32.2 & 34.1 \\
\hline Test $10 \mathrm{a}-$ & -e 28.5 & 32.0 & 32.4 & 33.1 & 33.3 & 34.3 \\
\hline Test $10 \mathrm{~b}$ & -a 20.0 & 21.3 & 21.6 & 21.9 & 22.3 & 24.4 \\
\hline Test $10 \mathrm{~b}-$ & -b 20.2 & 23.8 & 24.5 & 26.1 & 26.4 & 27.6 \\
\hline Test $10 \mathrm{~b}$ & -c 23.2 & 26.3 & 26.4 & 27.0 & 28.0 & 29.0 \\
\hline Test $10 \mathrm{c}-$ & -a 24.2 & 26.7 & 27.3 & 28.1 & 29.3 & 31.5 \\
\hline Test $10 c-$ & -b 26.9 & 30.3 & 31.4 & 31.9 & 32.5 & 33.5 \\
\hline Test $10 c-$ & -c 26.7 & 30.6 & 31.1 & 31.3 & 32.0 & 34.0 \\
\hline Test 11 & 24.7 & 26.4 & 27.2 & 27.8 & 28.9 & 32.4 \\
\hline
\end{tabular}




\section{Appendix B-4 (cont.).}

Gas temperature data collected in the middle of the test chamber.

\begin{tabular}{|c|c|c|c|c|c|c|}
\hline & & Average & Average & Average & Average & Maximum \\
\hline & Initial & Temperature & Temperature & Temperature & emperature & Observed \\
\hline & emperature & from & from & from & from & Temperatu \\
\hline & & $0-300 \mathrm{sec}$ & $300-600 \mathrm{sec}$ & $600-900 \mathrm{sec}$ & $900-1200 \mathrm{sec}$ & \\
\hline & $\left({ }^{\circ} \mathrm{C}\right)$ & $\left({ }^{\circ} \mathrm{C}\right)$ & $\left({ }^{\circ} \mathrm{C}\right)$ & $\left({ }^{\circ} \mathrm{C}\right)$ & $\left({ }^{\circ} \mathrm{C}\right)$ & $\left({ }^{\circ} \mathrm{C}\right)$ \\
\hline Test 1 & 25.7 & 31.8 & 36.3 & 40.2 & 41.4 & 46.2 \\
\hline Test $2 \mathrm{a}$ & 26.9 & 32.2 & 35.8 & 38.6 & 41.7 & 46.9 \\
\hline Test $2 b$ & 25.7 & 32.2 & 35.2 & 37.6 & 38.2 & 44.2 \\
\hline Test $3 a$ & 24.3 & 33.7 & 36.3 & 39.2 & 42.0 & 45.5 \\
\hline Test $3 b$ & 28.2 & 31.1 & 38.8 & 45.3 & 46.3 & 47.9 \\
\hline Test 4 & 27.3 & 39.9 & 47.5 & 47.0 & 47.9 & 49.6 \\
\hline Test 5 & 24.7 & 31.9 & 38.1 & 42.9 & 44.1 & 48.5 \\
\hline Test 6 & 25.4 & 33.8 & 39.6 & 43.6 & 45.4 & 48.2 \\
\hline Test 7a & 27.2 & 35.4 & 43.6 & 44.7 & 45.8 & 48.2 \\
\hline Test $7 \mathrm{~b}$ & 24.9 & 31.1 & 39.5 & 42.4 & 43.2 & 44.4 \\
\hline Test $7 c$ & 23.8 & 34.4 & 42.9 & 42.0 & 43.1 & 44.4 \\
\hline Test 8 & 27.0 & 33.0 & 39.0 & 43.7 & 45.9 & 47.5 \\
\hline Test 9-a & 26.9 & 33.2 & 38.7 & 42.9 & 43.1 & 45.9 \\
\hline Test 9-b & data lost & data lost & data lost & data lost & data lost & data lost \\
\hline Test 9-c & data lost & data lost & data lost & data lost & data lost & data lost \\
\hline Test 9-d & data lost & data lost & data lost & data lost & data lost & data lost \\
\hline Test 9-e & 22.1 & 29.4 & 33.5 & 37.1 & 39.7 & 43.2 \\
\hline Test $10 \mathrm{a}-\mathrm{a}$ & 23.8 & 30.6 & 34.2 & 36.4 & 40.2 & 43.3 \\
\hline Test $10 a-b$ & b 26.5 & 34.2 & 36.0 & 37.6 & 44.5 & 46.8 \\
\hline Test $10 a-c$ & 27.4 & 33.9 & 37.1 & 40.9 & 43.4 & 44.7 \\
\hline Test 10a-d & 28.9 & 35.5 & 40.0 & 41.4 & 43.9 & 47.5 \\
\hline Test 10a-e & 29.2 & 37.0 & 42.1 & 45.7 & 45.6 & 46.5 \\
\hline Test 10b-a & a 20.0 & 27.2 & 28.4 & 28.9 & 30.2 & 36.8 \\
\hline Test 10b-b & b 21.1 & 31.4 & 38.0 & 44.9 & 44.2 & 46.1 \\
\hline Test 10b-c & c 24.1 & 33.0 & 35.9 & 39.2 & 43.7 & 44.7 \\
\hline Test $10 c-a$ & a 24.6 & 30.6 & 37.0 & 42.2 & 45.6 & 48.0 \\
\hline Test $10 c-b$ & b 27.6 & 36.6 & 43.3 & 47.5 & 48.9 & 51.4 \\
\hline Test $10 c-c$ & 27.8 & 35.5 & 39.6 & 42.0 & 46.0 & 51.0 \\
\hline Test 11 & 24.9 & 31.3 & 36.9 & 41.3 & 44.7 & 45.8 \\
\hline
\end{tabular}


Appendix B-4 (cont.).

Gas temperature data collected at the top of the test chamber.

\begin{tabular}{|c|c|c|c|c|c|c|}
\hline & & Average & Average & Average & Average & Maximum \\
\hline & Initial & Temperature & Temperature & Temperature & Temperature & Observed \\
\hline & emperature & e from & from & from & from & Temperature \\
\hline & & $0-300 \mathrm{sec}$ & $300-600 \mathrm{sec}$ & $600-900$ & $0-1200 \mathrm{sec}$ & \\
\hline & $\left({ }^{\circ} \mathrm{C}\right)$ & $\left({ }^{\circ} \mathrm{C}\right)$ & $\left({ }^{\circ} \mathrm{C}\right)$ & $\left({ }^{\circ} \mathrm{C}\right)$ & $\left({ }^{\circ} \mathrm{C}\right)$ & $\left({ }^{\circ} \mathrm{C}\right)$ \\
\hline Test 1 & 26.3 & 32.2 & 39.4 & 46.9 & 47.5 & 53.1 \\
\hline Test $2 a$ & 29.3 & 33.6 & 40.6 & 47.0 & 49.8 & 54.7 \\
\hline Test $2 b$ & 26.2 & 33.8 & 40.4 & 45.6 & 46.1 & 50.4 \\
\hline Test 3a & 24.7 & 35.4 & 42.6 & 47.0 & 51.2 & 54.4 \\
\hline Test $3 b$ & 29.8 & 30.6 & 38.8 & 47.8 & 49.7 & 52.8 \\
\hline Test 4 & 29.4 & 41.4 & 50.6 & 53.2 & 54.9 & 60.3 \\
\hline Test 5 & 25.3 & 33.0 & 42.9 & 51.0 & 51.0 & 59.9 \\
\hline Test 6 & 26.8 & 37.9 & 46.0 & 51.3 & 53.7 & 58.2 \\
\hline Test 7a & 27.5 & 35.7 & 46.1 & 51.2 & 53.8 & 57.3 \\
\hline Test $7 \mathrm{~b}$ & 25.5 & 31.7 & 42.1 & 46.9 & 48.1 & 51.3 \\
\hline Test 7c & 24.2 & 35.2 & 44.8 & 47.4 & 49.2 & 51.5 \\
\hline Test 8 & 28.7 & 34.4 & 44.9 & 52.8 & 54.7 & 57.1 \\
\hline Test 9-a & 27.5 & 34.6 & 44.5 & 50.7 & 50.1 & 53.5 \\
\hline Test 9-b & data lost & data lost & data lost & data lost & data lost & data lost \\
\hline Test 9-c & data lost & data lost & data lost & data lost & data lost & data lost \\
\hline Test 9-d & data lost & data lost & data lost & data lost & data lost & data lost \\
\hline Test 9-e & 22.6 & 32.4 & 40.1 & 46.0 & 48.3 & 50.4 \\
\hline Test $10 \mathrm{a}-\mathrm{a}$ & a 23.8 & 33.9 & 42.1 & 44.7 & 47.9 & 53.7 \\
\hline Test $10 \mathrm{a}-\mathrm{b}$ & b 29.0 & 37.1 & 44.3 & 46.3 & 52.2 & 56.2 \\
\hline Test $10 a-c$ & c 30.2 & 35.4 & 41.5 & 46.8 & 50.4 & 52.7 \\
\hline Test $10 \mathrm{a}-\mathrm{d}$ & d 31.9 & 36.7 & 45.2 & 49.2 & 51.7 & 57.1 \\
\hline Test 10a-e & e 32.3 & 38.5 & 46.5 & 52.2 & 51.8 & 54.3 \\
\hline Test $10 \mathrm{~b}-\mathrm{a}$ & a 20.2 & 30.8 & 33.0 & 34.3 & 34.9 & 44.1 \\
\hline Test $10 \mathrm{~b}-\mathrm{b}$ & b 24.4 & 35.9 & 46.6 & 54.6 & 53.0 & 57.5 \\
\hline Test $10 \mathrm{~b}-\mathrm{c}$ & c 27.3 & 37.4 & 43.6 & 47.0 & 53.2 & 56.0 \\
\hline Test $10 c-a$ & a 26.6 & 32.5 & 44.8 & 50.9 & 54.1 & 57.3 \\
\hline Test $10 c-b$ & b 31.8 & 39.5 & 51.0 & 54.9 & 57.2 & 60.1 \\
\hline Test $10 c-c$ & c 32.6 & 39.0 & 48.5 & 49.1 & 55.6 & 60.3 \\
\hline Test 11 & 25.4 & 33.1 & 43.7 & 50.3 & 54.1 & 55.9 \\
\hline
\end{tabular}


Appendix B-4 (cont.).

Gas temperature data collected at the exit to the test chamber.

\begin{tabular}{|c|c|c|c|c|c|c|}
\hline & & Average & Average & Average & Average & Maximum \\
\hline & Initial & Temperature & Temperature & Temperature & Temperature & Observed \\
\hline & emperature & from & from & from & from & Temperature \\
\hline & & $0-300 \mathrm{sec}$ & $300-600 \mathrm{sec}$ & $600-900 \mathrm{sec}$ & $900-1200 \mathrm{sec}$ & \\
\hline & $\left({ }^{\circ} \mathrm{C}\right)$ & & $\left({ }^{\circ} \mathrm{C}\right)$ & $\left({ }^{\circ} \mathrm{C}\right)$ & $\left({ }^{\circ} \mathrm{C}\right)$ & $\left({ }^{\circ} \mathrm{C}\right)$ \\
\hline Test 1 & 25.5 & 32.1 & 38.9 & 45.0 & 46.4 & 51.8 \\
\hline Test $2 \mathrm{a}$ & 26.8 & 33.0 & 40.1 & 44.5 & 48.4 & 52.9 \\
\hline Test $2 \mathrm{~b}$ & 25.6 & 33.7 & 39.5 & 42.7 & 43.4 & 48.9 \\
\hline Test $3 a$ & 24.3 & 34.8 & 41.1 & 45.9 & 50.3 & 51.5 \\
\hline Test $3 b$ & 28.0 & 30.8 & 38.8 & 47.3 & 49.2 & 51.3 \\
\hline Test 4 & 27.3 & 40.8 & 49.8 & 51.9 & 53.4 & 57.2 \\
\hline Test 5 & 24.8 & 31.9 & 41.5 & 48.1 & 48.8 & 54.7 \\
\hline Test 6 & 25.4 & 36.7 & 45.1 & 49.8 & 51.7 & 54.9 \\
\hline Test $7 \mathrm{a}$ & 27.2 & 35.3 & 45.5 & 49.3 & 51.6 & 54.1 \\
\hline Test 7b & 24.9 & 31.3 & 42.1 & 46.4 & 47.5 & 49.0 \\
\hline Test 7c & 23.8 & 34.7 & 44.8 & 46.5 & 48.6 & 50.0 \\
\hline Test 8 & 27.0 & 33.4 & 43.8 & 50.5 & 52.7 & 53.7 \\
\hline Test 9-a & 26.9 & 34.9 & 43.9 & 49.7 & 49.4 & 51.9 \\
\hline Test 9-b & data lost & data lost & data lost & data lost & data lost & data lost \\
\hline Test 9-c & data lost & data lost & data lost & data lost & data lost & data lost \\
\hline Test 9-d & data lost & data lost & data lost & data lost & data lost & data lost \\
\hline Test 9-e & 22.7 & 32.1 & 39.0 & 43.6 & 46.8 & 48.3 \\
\hline Test 10a-a & 23.8 & 33.4 & 40.4 & 43.1 & 46.7 & 50.4 \\
\hline Test $10 a-b$ & 26.4 & 36.4 & 41.8 & 43.8 & 50.9 & 53.5 \\
\hline Test $10 a-c$ & 27.3 & 35.0 & 41.3 & 46.1 & 49.5 & 50.5 \\
\hline Test 10a-d & 28.6 & 36.3 & 45.1 & 48.0 & 50.0 & 54.2 \\
\hline Test 10a-e & 29.0 & 38.4 & 46.2 & 51.1 & 50.9 & 52.1 \\
\hline Test $10 \mathrm{~b}-\mathrm{a}$ & a 19.9 & 30.5 & 33.0 & 34.3 & 35.1 & 42.6 \\
\hline Test $10 b-b$ & 21.1 & 35.5 & 44.7 & 52.9 & 51.5 & 54.9 \\
\hline Test $10 \mathrm{~b}-\mathrm{c}$ & 24.0 & 36.7 & 43.1 & 45.5 & 51.6 & 52.4 \\
\hline Test $10 c-a$ & 24.6 & 32.0 & 42.9 & 49.4 & 52.2 & 54.5 \\
\hline Test $10 c-b$ & 27.6 & 38.5 & 48.9 & 54.3 & 56.8 & 58.2 \\
\hline Test $10 c-c$ & 27.8 & 37.2 & 45.2 & 47.8 & 53.3 & 57.8 \\
\hline Test 11 & 25.0 & 32.8 & 42.3 & 48.5 & 52.2 & 53.2 \\
\hline
\end{tabular}


Appendix B-4 (cont.).

Ambient gas temperature data collected outside the test chamber.

\begin{tabular}{|c|c|c|c|c|c|c|}
\hline & & Average & Average & Average & Average & Maximum \\
\hline & Initial & Temperature & Temperature & Temperature & Temperatur & Observed \\
\hline & [emperature & from & from & from & from & Temperature \\
\hline & $\left({ }^{\circ} \mathrm{C}\right)$ & $\begin{array}{c}0-300 \mathrm{sec} \\
\left({ }^{\circ} \mathrm{C}\right)\end{array}$ & $\begin{array}{c}300-600 \mathrm{sec} \\
\left({ }^{\circ} \mathrm{C}\right)\end{array}$ & $\begin{array}{c}600-900 \mathrm{sec} \\
\left({ }^{\circ} \mathrm{C}\right)\end{array}$ & $\begin{array}{c}900-1200 \mathrm{sec} \\
\left({ }^{\circ} \mathrm{C}\right)\end{array}$ & $\left({ }^{\circ} \mathrm{C}\right)$ \\
\hline Test 1 & 26.1 & 25.9 & 26.2 & 26.5 & 26.6 & 28.4 \\
\hline Test $2 a$ & 25.7 & 25.6 & 25.7 & 25.9 & 25.8 & 27.0 \\
\hline Test $2 b$ & 26.1 & 26.5 & 26.8 & 27.2 & 27.5 & 31.6 \\
\hline Test $3 a$ & 24.8 & 25.2 & 25.2 & 25.6 & 26.4 & 28.2 \\
\hline Test 3b & 28.2 & 27.9 & 28.0 & 28.2 & 28.5 & 29.4 \\
\hline Test 4 & 27.0 & 27.2 & 27.4 & 27.6 & 27.7 & 26.0 \\
\hline Test 5 & 25.7 & 25.6 & 26.0 & 26.5 & 27.2 & 28.7 \\
\hline Test 6 & 25.5 & 25.6 & 26.0 & 26.1 & 26.5 & 27.9 \\
\hline Test 7a & 27.5 & 27.5 & 27.6 & 28.0 & 28.3 & 29.8 \\
\hline Test $7 b$ & 25.6 & 25.6 & 25.9 & 26.5 & 26.9 & 28.1 \\
\hline Test 7c & 24.4 & 24.6 & 24.9 & 25.5 & 26.1 & 27.1 \\
\hline Test 8 & 26.2 & 26.0 & 26.1 & 26.3 & 26.9 & 28.0 \\
\hline Test 9-a & 27.4 & 27.5 & 28.0 & 28.4 & 28.7 & 30.1 \\
\hline Test 9-b & data lost & data lost & data lost & data lost & data lost & data lost \\
\hline Test 9-c & data lost & data lost & data lost & data lost & data lost & data lost \\
\hline Test 9-d & data lost & data lost & data lost & data lost & data lost & data lost \\
\hline Test 9-e & 22.2 & 22.6 & 23.0 & 23.7 & 24.1 & 26.8 \\
\hline Test $10 \mathrm{a}-\mathrm{a}$ & a 24.2 & 24.2 & 24.5 & 25.0 & 25.3 & 26.2 \\
\hline Test 10a-b & b 25.2 & 25.7 & 25.9 & 26.2 & 26.6 & 27.9 \\
\hline Test $10 \mathrm{a}-\mathrm{c}$ & c 27.0 & 26.8 & 27.3 & 27.7 & 27.8 & 28.8 \\
\hline Test 10a-d & d 27.8 & 28.1 & 28.4 & 28.7 & 29.1 & 30.2 \\
\hline Test 10a-e & e 28.9 & 29.0 & 29.1 & 29.4 & 29.5 & 30.8 \\
\hline Test $10 \mathrm{~b}-\mathrm{a}$ & a 20.4 & 20.6 & 21.2 & 21.6 & 22.0 & 22.9 \\
\hline Test $10 \mathrm{~b}-\mathrm{b}$ & b 20.6 & 21.8 & 22.7 & 23. & 24.4 & 25.1 \\
\hline Test $10 \mathrm{~b}-\mathrm{c}$ & c 23.4 & 23.5 & 24.2 & 24.6 & 24.8 & 26.3 \\
\hline Test $10 \mathrm{c}-\mathrm{a}$ & a 24.7 & 24.8 & 25.2 & 25.7 & 26.2 & 28.7 \\
\hline Test $10 \mathrm{c}-\mathrm{b}$ & b 27.2 & 26.8 & 27.0 & 28.0 & 28.6 & 29.2 \\
\hline Test $10 \mathrm{c}-\mathrm{c}$ & c 27.3 & 27.1 & 27.3 & 28.0 & 28.2 & 29.8 \\
\hline st 11 & 25.7 & 25.9 & 26.3 & 267 & 27.1 & 28.9 \\
\hline
\end{tabular}


Appendix B-4 (cont.).

Gas temperature data collected at the test filter holder.

\begin{tabular}{|c|c|c|c|c|c|c|}
\hline & & Average & Average & Average & Average & Maximum \\
\hline & Initial & Temperatur & Temperature & Temperature & Temperature & $\begin{array}{l}\text { Observed } \\
\text { Temperature }\end{array}$ \\
\hline & lemperature & $\begin{array}{c}\text { trom } \\
0-300 \mathrm{sec}\end{array}$ & $\begin{array}{c}\text { from } \\
300-600 \mathrm{sec}\end{array}$ & $\begin{array}{c}\text { from } \\
600-900 \mathrm{sec}\end{array}$ & $\begin{array}{l}\text { from } \\
900-1200 \mathrm{sec}\end{array}$ & Iemperature \\
\hline & $\left({ }^{\circ} \mathrm{C}\right)$ & $\left({ }^{\circ} \mathrm{C}\right)$ & $\left({ }^{\circ} \mathrm{C}\right)$ & $\left({ }^{\circ} \mathrm{C}\right)$ & $\left({ }^{\circ} \mathrm{C}\right)$ & $\left({ }^{\circ} \mathrm{C}\right)$ \\
\hline Test & 25.8 & 26.0 & 26.5 & 27.2 & 28.0 & 28.2 \\
\hline Test 2a & 26.1 & 26.3 & 27.0 & 27.8 & 28.5 & 28.9 \\
\hline Test $2 b$ & 25.7 & 26.0 & 26.8 & 27.6 & 28.2 & 28.4 \\
\hline Test 3a & 24.3 & 24.7 & 25.4 & 26.2 & 27.0 & 27.4 \\
\hline est $3 b$ & 27.6 & 27.7 & 28.0 & 28.8 & 29.5 & 29.8 \\
\hline Test 2 & 26.5 & 27.7 & 29.3 & 30.1 & 30.6 & 30.9 \\
\hline Test 5 & 24.8 & 25.0 & 26.0 & 26.8 & 27.5 & 27.8 \\
\hline Test 6 & 25.5 & 26.0 & 27.0 & 27.7 & 28.2 & 28.5 \\
\hline Test $7 \mathrm{a}$ & 26.9 & 27.2 & 27.9 & 28.4 & 29.2 & 29.7 \\
\hline Test $7 \mathrm{~b}$ & 25.0 & 25.3 & 26.3 & 27.3 & 28.1 & 28.4 \\
\hline Test 7c & 24.0 & 24.6 & 25.8 & 26.9 & 27.7 & 28.0 \\
\hline Test 8 & 26.1 & 26.4 & 27.8 & 29.3 & 30.5 & 31.1 \\
\hline Test 9-a & 26.8 & 27.5 & 29.3 & 31.0 & 32.0 & 33.4 \\
\hline est 9-b & data lost & data lost & data lost & data lost & data lost & data lost \\
\hline Test 9-c & data lost & data lost & data lost & data lost & data lost & data lost \\
\hline Test 9-d & data lost & data lost & data lost & data lost & data lost & data lost \\
\hline Test 9-e & 21.0 & 22.4 & 24.0 & 25.2 & 26.3 & 29.6 \\
\hline Test $10 \mathrm{a}-\mathrm{a}$ & a 23.4 & 24.6 & 26.4 & 27.7 & 28.8 & 29.2 \\
\hline Test $10 \mathrm{a}-\mathrm{b}$ & b $\quad 25.8$ & 26.8 & 28.5 & 29.6 & 30.9 & 31.6 \\
\hline Test $10 \mathrm{a}-\mathrm{c}$ & c 27.4 & 27.8 & 29.2 & 30.4 & 31.5 & 31.9 \\
\hline Test $10 \mathrm{a}-\mathrm{d}$ & d 28.3 & 28.8 & 30.5 & 31.9 & 32.8 & 33.3 \\
\hline Test 10 & e 29.0 & 29.6 & 31.3 & 32.8 & 33.7 & 34.0 \\
\hline Test $10 \mathrm{~b}-\mathrm{a}$ & -a 20.2 & 21.3 & 22.6 & 23.4 & 24.0 & 24.3 \\
\hline Test $10 \mathrm{~b}-\mathrm{b}$ & b 20.7 & 22.5 & 25.0 & 26.7 & 28.0 & 28.5 \\
\hline Test $10 \mathrm{~b}-\mathrm{c}$ & c 23.4 & 24.4 & 25.8 & 26.9 & 28.1 & 28.4 \\
\hline Test $10 \mathrm{c}-\mathrm{a}$ & a 24.0 & 24.8 & 26.7 & 28.4 & 29.8 & 30.3 \\
\hline Test $10 c-b$ & b 25.9 & 27. & 29.2 & 30.9 & 32.4 & 32.7 \\
\hline Test $10 c-c$ & c 27.7 & 27.8 & 29.3 & 30.4 & 31.5 & 32.1 \\
\hline Test 11 & 24.8 & 25.6 & 27.5 & 29.3 & 30.7 & 32.4 \\
\hline
\end{tabular}


Appendix B-4 (cont.).

Gas temperature data collected at the exhaust flow orifice.

\begin{tabular}{|c|c|c|c|c|c|c|}
\hline & & Average & Average & Average & Average & Maximum \\
\hline & Initial & Temperature & Temperature & Temperature & Temperature & Observed \\
\hline & emperature & from & from & from & from & Temperat \\
\hline & & $0-300 \mathrm{sec}$ & $300-600 \mathrm{sec}$ & $600-900 \mathrm{~s}$ & $00-1200 \mathrm{sec}$ & \\
\hline & $\left({ }^{\circ} \mathrm{C}\right)$ & $\left({ }^{\circ} \mathrm{C}\right)$ & $\left({ }^{\circ} \mathrm{C}\right)$ & $\left({ }^{\circ} \mathrm{C}\right)$ & $\left({ }^{\circ} \mathrm{C}\right)$ & $\left({ }^{\circ} \mathrm{C}\right)$ \\
\hline Test 1 & 25.9 & 28.2 & 32.0 & 35.5 & 37.3 & 40.0 \\
\hline Test $2 \mathrm{a}$ & 27.1 & 28.7 & 31.8 & 34.5 & 36.2 & 39.1 \\
\hline Test 2b & 25.8 & 28.2 & 31.3 & 33.5 & 34.6 & 37.9 \\
\hline Test $3 a$ & 24.6 & 28.8 & 33.1 & 35.8 & 38.4 & 39.7 \\
\hline Test 3b & 28.2 & 29.2 & 32.0 & 37.0 & 38.8 & 40.0 \\
\hline Test 4 & 27.3 & 32.4 & 37.8 & 40.2 & 41.4 & 43.2 \\
\hline Test 5 & 24.8 & 27.5 & 32.8 & 36.8 & 38.6 & 41.6 \\
\hline Test 6 & 25.6 & 29.4 & 33.9 & 36.5 & 38.2 & 40.2 \\
\hline Test $7 \mathrm{a}$ & 27.3 & 30.0 & 35.4 & 38.4 & 40.5 & 42.3 \\
\hline Test 7b & 25.1 & 27.3 & 32.8 & 36.1 & 37.7 & 38.1 \\
\hline Test $7 c$ & 24.1 & 28.1 & 34.2 & 36.6 & 38.1 & 38.9 \\
\hline Test 8 & 26.7 & 28.9 & 34.4 & 38.5 & 40.8 & 41.4 \\
\hline Test 9-a & 26.9 & 29.3 & 33.6 & 36.7 & 37.9 & 39.6 \\
\hline Test 9-b & data lost & data lost & data lost & data lost & data lost & data lost \\
\hline Test 9-c & data lost & data lost & data lost & data lost & data lost & data lost \\
\hline Test 9-d & data lost & data lost & data lost & data lost & data lost & data lost \\
\hline Test 9-e & 22.0 & 25.1 & 28.7 & 31.0 & 32.8 & 35.9 \\
\hline Test $10 \mathrm{a}-\mathrm{a}$ & a 24.2 & 27.1 & 31.1 & 33.3 & 34.8 & 36.7 \\
\hline Test $10 \mathrm{a}-\mathrm{b}$ & b 26.7 & 29.6 & 32.9 & 34.5 & 36.8 & 38.6 \\
\hline Test $10 \mathrm{a}-\mathrm{c}$ & c 27.6 & 29.6 & 32.9 & 35.2 & 37.1 & 38.2 \\
\hline Test $10 \mathrm{a}-\mathrm{d}$ & d 29.0 & 30.7 & 34.7 & 37.1 & 38.2 & 40.1 \\
\hline Test 10a-e & e 29.4 & 31.8 & 35.5 & 38.4 & 39.4 & 39.6 \\
\hline Test $10 \mathrm{~b}-\mathrm{a}$ & a 20.5 & 24.0 & 26.0 & 27.0 & 27.6 & 30.4 \\
\hline Test $10 \mathrm{~b}-\mathrm{b}$ & b 21.4 & 25.7 & 30.2 & 33.5 & 34.7 & 35.0 \\
\hline Test $10 \mathrm{~b}-\mathrm{c}$ & c 24.3 & 27.3 & 30.7 & 32.2 & 34.6 & 35.3 \\
\hline Test $10 \mathrm{c}-\mathrm{a}$ & a 24.6 & 26.5 & 31.0 & 34.0 & 36.1 & 38.8 \\
\hline Test $10 \mathrm{c}-\mathrm{b}$ & b 27.4 & 30.1 & 34.8 & 37.8 & 40.0 & 40.5 \\
\hline Test $10 c-c$ & c 27.7 & 30.0 & 34.2 & 35.9 & 37.9 & 41.4 \\
\hline Test 11 & 25.3 & 27.6 & 32.1 & 35.5 & 37.9 & 39.1 \\
\hline
\end{tabular}


Appendix B-5.

Particulate Data.

\begin{tabular}{|c|c|c|c|c|c|}
\hline Upstream & Downstream & Upstream & Downstream & Upstream & Downstream \\
\hline Initial & Initial & Final & Final & Air & Air \\
\hline Filter & Filter & Filter & Filter & Particulate & Particulate \\
\hline $\begin{array}{c}\text { Mass } \\
\text { (grams) }\end{array}$ & $\begin{array}{c}\text { Mass } \\
\text { (grams) }\end{array}$ & $\begin{array}{l}\text { Mass } \\
\text { (grams) }\end{array}$ & $\begin{array}{c}\text { Mass } \\
\text { (grams) }\end{array}$ & $\begin{array}{c}\text { Density } \\
\left(\mathrm{g} / \mathrm{m}^{3}\right)\end{array}$ & $\begin{array}{c}\text { Density } \\
\left(\mathrm{g} / \mathrm{m}^{3}\right)\end{array}$ \\
\hline
\end{tabular}

$\begin{array}{lllllll}\text { Test 1 } & 0.124 & 0.128 & 0.196 & 0.192 & 1.80 & 1.60 \\ \text { Test 2a } & 0.125 & 0.124 & 0.221 & 0.214 & 2.40 & 2.25 \\ \text { Test 2b } & 0.127 & 0.123 & 0.219 & 0.203 & 2.30 & 2.00 \\ \text { Test 3a } & 0.124 & 0.124 & 0.225 & 0.214 & 2.53 & 2.25 \\ \text { Test 3b } & 0.123 & 0.127 & 0.201 & 0.195 & 1.96 & 1.70 \\ \text { Test 4 } & 0.128 & 0.125 & 0.229 & 0.211 & 2.53 & 2.15 \\ \text { Test 5 } & 0.125 & 0.127 & 0.219 & 0.167 & 2.35 & 1.00 \\ \text { Test 6 } & 0.126 & 0.126 & 0.242 & 0.181 & 2.90 & 1.38 \\ \text { Test 7a } & 0.127 & 0.124 & 0.212 & 0.136 & 2.13 & 0.30 \\ \text { Test 7b } & 0.124 & 0.126 & 0.211 & 0.141 & 2.19 & 0.36 \\ \text { Test 7c } & 0.122 & 0.124 & 0.209 & 0.137 & 2.16 & 0.33 \\ \text { Test 8 } & 0.127 & 0.125 & 0.202 & 0.139 & 1.88 & 0.35 \\ & & & & & & \\ \text { Test 9-a } & 0.124 & 0.129 & 0.221 & 0.147 & 2.43 & 0.45 \\ \text { Test 10a-a } & 0.127 & 0.124 & 0.230 & 0.147 & 2.58 & 0.58 \\ \text { Test 10a-b } & 0.128 & 0.126 & 0.244 & 0.155 & 2.90 & 0.73 \\ \text { Test 10a-c } & 0.124 & 0.125 & 0.222 & 0.146 & 2.45 & 0.53 \\ \text { Test 10a-d } & 0.126 & 0.124 & 0.237 & 0.149 & 2.78 & 0.63 \\ \text { Test 10a-e } & 0.128 & 0.124 & 0.205 & 0.142 & 1.93 & 0.45 \\ \text { Test 10b-a } & 0.124 & 0.125 & 0.190 & 0.138 & 1.65 & 0.32 \\ \text { Test 10b-b } & 0.123 & 0.128 & 0.256 & 0.168 & 3.34 & 1.01 \\ \text { Test 10b-c } & 0.125 & 0.125 & 0.258 & 0.165 & 3.34 & 1.02 \\ \text { Test 10c-a } & 0.124 & 0.124 & 0.270 & 0.156 & 3.65 & 0.81 \\ \text { Test 10c-b } & 0.124 & 0.123 & 0.247 & 0.153 & 3.07 & 0.74 \\ \text { Test 10c-c } & 0.124 & 0.123 & 0.247 & 0.153 & 3.07 & 0.74 \\ & & & & & & \\ \text { Test 11 } & 0.127 & 0.125 & 0.235 & 0.125 & 2.70 & 0.00\end{array}$


Appendix B-6.

Pressure differential across the test filter data.

\begin{tabular}{|c|c|c|c|c|c|c|}
\hline & $\begin{array}{c}\text { Initial } \\
\text { Delta } \\
\text { Pressure } \\
\\
\text { (Pascals) }\end{array}$ & $\begin{array}{l}\text { Average } \\
\text { Delta } \\
\text { Pressure } \\
\text { from } \\
0-300 \mathrm{sec} \\
\text { (Pascals) }\end{array}$ & $\begin{array}{l}\text { Average } \\
\text { Delta } \\
\text { Pressure } \\
\text { from } \\
300-600 \mathrm{sec} \\
\text { (Pascals) }\end{array}$ & $\begin{array}{c}\text { Average } \\
\text { Delta } \\
\text { Pressure } \\
\text { from } \\
\text { 600-900 sec } \\
\text { (Pascals) }\end{array}$ & $\begin{array}{c}\text { Average } \\
\text { Delta } \\
\text { Pressure } \\
\text { from } \\
900-1200 \mathrm{sec} \\
\text { (Pascals) }\end{array}$ & $\begin{array}{l}\text { Maximum } \\
\text { Delta } \\
\text { Pressure } \\
\text { Observed } \\
\\
\text { (Pascals) }\end{array}$ \\
\hline $\begin{array}{l}\text { Test } 1 \\
\text { Test } 2 \mathrm{a} \\
\text { Test } 2 \mathrm{~b} \\
\text { Test } 3 \mathrm{a} \\
\text { Test } 3 \mathrm{~b} \\
\text { Test } 4 \\
\text { Test } 5 \\
\text { Test } 6 \\
\text { Test 7a } \\
\text { Test } 7 \mathrm{~b} \\
\text { Test } 7 \mathrm{c} \\
\text { Test } 8\end{array}$ & $\begin{array}{c}0 \\
0 \\
1 \\
-2 \\
0 \\
-2 \\
-1 \\
-1 \\
1 \\
2 \\
3 \\
-2\end{array}$ & $\begin{array}{c}1 \\
1 \\
5 \\
2 \\
3 \\
5 \\
95 \\
92 \\
98 \\
145 \\
145 \\
194\end{array}$ & $\begin{array}{c}2 \\
1 \\
6 \\
1 \\
3 \\
4 \\
99 \\
94 \\
115 \\
147 \\
147 \\
220\end{array}$ & $\begin{array}{c}1 \\
1 \\
5 \\
1 \\
4 \\
3 \\
98 \\
90 \\
110 \\
150 \\
150 \\
213\end{array}$ & $\begin{array}{c}1 \\
2 \\
5 \\
1 \\
4 \\
2 \\
85 \\
72 \\
110 \\
147 \\
149 \\
207\end{array}$ & $\begin{array}{c}7 \\
5 \\
9 \\
8 \\
8 \\
9 \\
111 \\
12 \\
136 \\
161 \\
159 \\
245\end{array}$ \\
\hline $\begin{array}{l}\text { Test 9-a } \\
\text { Test 9-b } \\
\text { Test 9-c } \\
\text { Test 9-d } \\
\text { Test 9-e }\end{array}$ & $\begin{array}{c}-2 \\
\text { data lost } \\
\text { data lost } \\
\text { data lost } \\
0\end{array}$ & $\begin{array}{c}344 \\
\text { data lost } \\
\text { data lost } \\
\text { data lost } \\
506\end{array}$ & $\begin{array}{c}363 \\
\text { data lost } \\
\text { data lost } \\
\text { data lost } \\
873\end{array}$ & $\begin{array}{c}374 \\
\text { data lost } \\
\text { data lost } \\
\text { data lost } \\
1413\end{array}$ & $\begin{array}{c}375 \\
\text { data lost } \\
\text { data lost } \\
\text { data lost } \\
1501\end{array}$ & $\begin{array}{c}385 \\
\text { data lost } \\
\text { data lost } \\
\text { data lost } \\
1535\end{array}$ \\
\hline $\begin{array}{l}\text { Test } 10 a-a \\
\text { Test } 10 a-b \\
\text { Test } 10 a-c \\
\text { Test } 10 a-d \\
\text { Test } 10 a-e \\
\text { Test } 10 b-a \\
\text { Test } 10 b-b \\
\text { Test } 10 b-c \\
\text { Test } 10 c-a \\
\text { Test } 10 c-b \\
\text { Test } 10 c-c\end{array}$ & $\begin{array}{l}2 \\
0 \\
0 \\
2 \\
-2 \\
2 \\
0 \\
3 \\
1 \\
1 \\
1\end{array}$ & $\begin{array}{l}323 \\
368 \\
401 \\
447 \\
473 \\
336 \\
370 \\
388 \\
320 \\
380 \\
406\end{array}$ & $\begin{array}{l}330 \\
401 \\
415 \\
483 \\
505 \\
345 \\
393 \\
391 \\
352 \\
407 \\
439\end{array}$ & $\begin{array}{l}327 \\
401 \\
413 \\
485 \\
513 \\
348 \\
388 \\
383 \\
361 \\
414 \\
432\end{array}$ & $\begin{array}{l}322 \\
405 \\
408 \\
485 \\
511 \\
350 \\
382 \\
368 \\
364 \\
414 \\
439\end{array}$ & $\begin{array}{l}339 \\
418 \\
422 \\
494 \\
523 \\
359 \\
399 \\
402 \\
370 \\
423 \\
448\end{array}$ \\
\hline Test 11 & -1 & 329 & 344 & 352 & 359 & 367 \\
\hline
\end{tabular}


Appendix B-6 (cont.).

Pressure differential across the chamber exhaust orifice data.

\begin{tabular}{|c|c|c|c|c|c|}
\hline & $\begin{array}{l}\text { Average } \\
\text { Delta } \\
\text { Pressure } \\
\text { from } \\
0-300 \mathrm{sec} \\
\text { (Pascals) }\end{array}$ & $\begin{array}{c}\text { Average } \\
\text { Delta } \\
\text { Pressure } \\
\text { from } \\
300-600 \mathrm{sec} \\
\text { (Pascals) }\end{array}$ & $\begin{array}{l}\text { Average } \\
\text { Delta } \\
\text { Pressure } \\
\text { from } \\
600-900 \mathrm{sec} \\
\text { (Pascals) }\end{array}$ & $\begin{array}{c}\text { Average } \\
\text { Delta } \\
\text { Pressure } \\
\text { from } \\
900-1200 \mathrm{sec} \\
\text { (Pascals) }\end{array}$ & $\begin{array}{c}\text { Maximum } \\
\text { Delta } \\
\text { Pressure } \\
\text { Observed } \\
\text { (Pascals) }\end{array}$ \\
\hline $\begin{array}{l}\text { Test } 1 \\
\text { Test } 2 \mathrm{a} \\
\text { Test } 2 \mathrm{~b} \\
\text { Test } 3 \mathrm{a} \\
\text { Test } 3 \mathrm{~b} \\
\text { Test } 4 \\
\text { Test } 5 \\
\text { Test } 6 \\
\text { Test } 7 \mathrm{a} \\
\text { Test } 7 \mathrm{~b} \\
\text { Test } 7 \mathrm{c} \\
\text { Test } 8\end{array}$ & $\begin{array}{l}0.131 \\
0.080 \\
0.055 \\
0.132 \\
0.130 \\
0.130 \\
0.130 \\
0.081 \\
0.131 \\
0.132 \\
0.133 \\
0.130\end{array}$ & $\begin{array}{l}0.131 \\
0.079 \\
0.057 \\
0.132 \\
0.130 \\
0.129 \\
0.130 \\
0.081 \\
0.130 \\
0.132 \\
0.133 \\
0.131\end{array}$ & $\begin{array}{l}0.132 \\
0.078 \\
0.057 \\
0.132 \\
0.131 \\
0.120 \\
0.130 \\
0.081 \\
0.130 \\
0.132 \\
0.133 \\
0.131\end{array}$ & $\begin{array}{l}0.118 \\
0.078 \\
0.057 \\
0.131 \\
0.131 \\
0.124 \\
0.130 \\
0.081 \\
0.130 \\
0.132 \\
0.132 \\
0.131\end{array}$ & $\begin{array}{l}0.137 \\
0.084 \\
0.066 \\
0.139 \\
0.139 \\
0.138 \\
0.139 \\
0.086 \\
0.138 \\
0.141 \\
0.142 \\
0.140\end{array}$ \\
\hline $\begin{array}{l}\text { Test 9-a } \\
\text { Test 9-b } \\
\text { Test 9-c } \\
\text { Test 9-d } \\
\text { Test 9-e }\end{array}$ & $\begin{array}{c}0.073 \\
\text { data lost } \\
\text { data lost } \\
\text { data lost } \\
0.046\end{array}$ & $\begin{array}{l}0.072 \\
\text { data lost } \\
\text { data lost } \\
\text { data lost } \\
0.044\end{array}$ & $\begin{array}{c}0.072 \\
\text { data lost } \\
\text { data lost } \\
\text { data lost } \\
0.044\end{array}$ & $\begin{array}{c}0.072 \\
\text { data lost } \\
\text { data lost } \\
\text { data lost } \\
0.044\end{array}$ & $\begin{array}{c}0.078 \\
\text { data lost } \\
\text { data lost } \\
\text { data lost } \\
0.068\end{array}$ \\
\hline $\begin{array}{l}\text { Test } 10 a-a \\
\text { Test } 10 a-b \\
\text { Test } 10 a-c \\
\text { Test } 10 a-d \\
\text { Test } 10 a-e \\
\text { Test } 10 b-a \\
\text { Test } 10 b-b \\
\text { Test } 10 b-c \\
\text { Test } 10 c-a \\
\text { Test } 10 c-b \\
\text { Test } 10 c-c\end{array}$ & $\begin{array}{l}0.066 \\
0.064 \\
0.068 \\
0.070 \\
0.072 \\
0.052 \\
0.043 \\
0.044 \\
0.046 \\
0.057 \\
0.058\end{array}$ & $\begin{array}{l}0.066 \\
0.064 \\
0.068 \\
0.070 \\
0.073 \\
0.049 \\
0.043 \\
0.042 \\
0.046 \\
0.059 \\
0.060\end{array}$ & $\begin{array}{l}0.066 \\
0.065 \\
0.069 \\
0.070 \\
0.073 \\
0.048 \\
0.045 \\
0.044 \\
0.050 \\
0.060 \\
0.061\end{array}$ & $\begin{array}{l}0.066 \\
0.065 \\
0.070 \\
0.071 \\
0.075 \\
0.048 \\
0.044 \\
0.045 \\
0.051 \\
0.061 \\
0.063\end{array}$ & $\begin{array}{l}0.140 \\
0.137 \\
0.140 \\
0.136 \\
0.134 \\
0.059 \\
0.132 \\
0.135 \\
0.061 \\
0.138 \\
0.073\end{array}$ \\
\hline Test 11 & 0.071 & 0.071 & 0.072 & 0.072 & 0.076 \\
\hline
\end{tabular}


Appendix C

Plots of Experimental Data 
Appendix C-1.

Gas chromatograph calibration curve for formaldehyde.

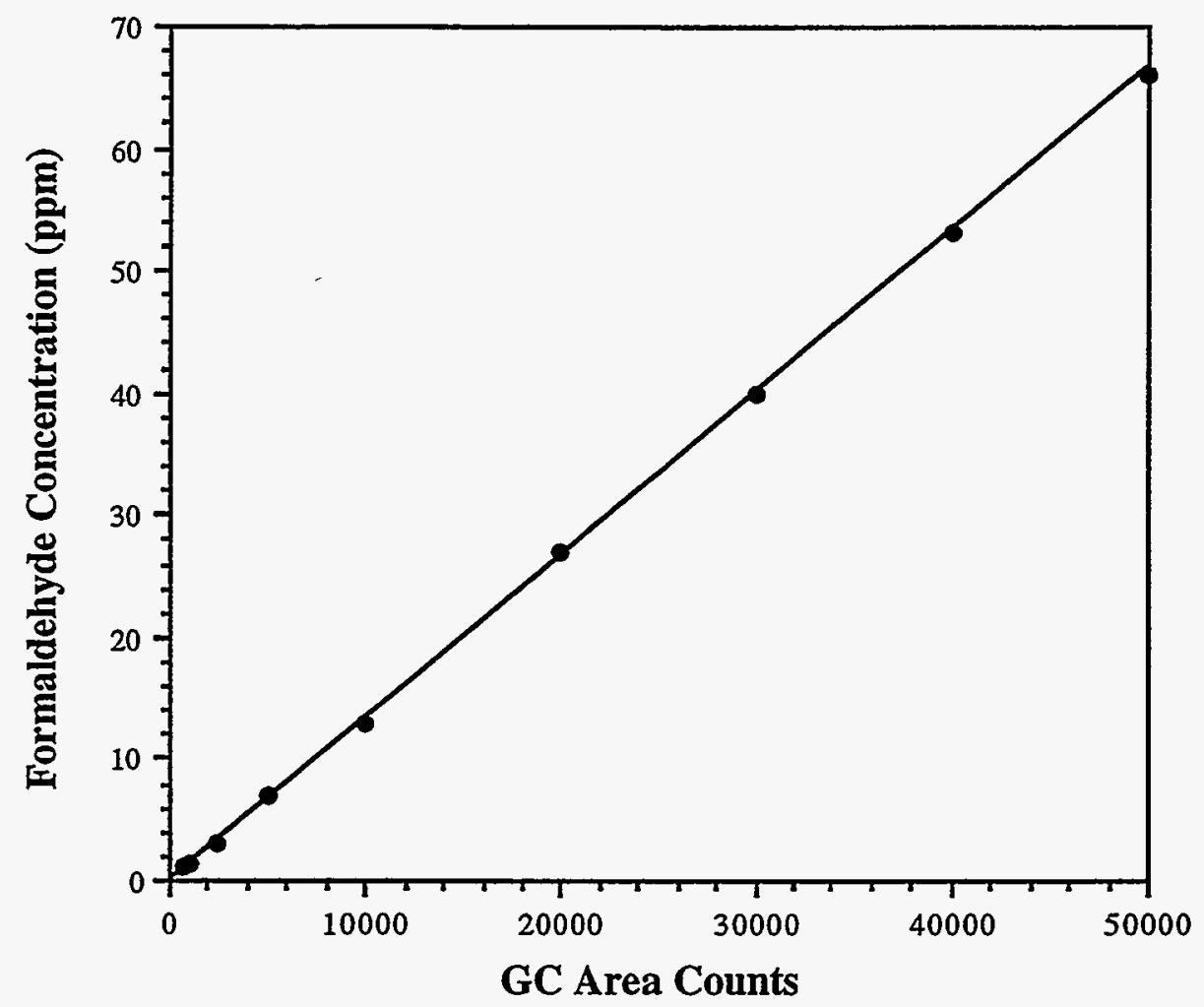



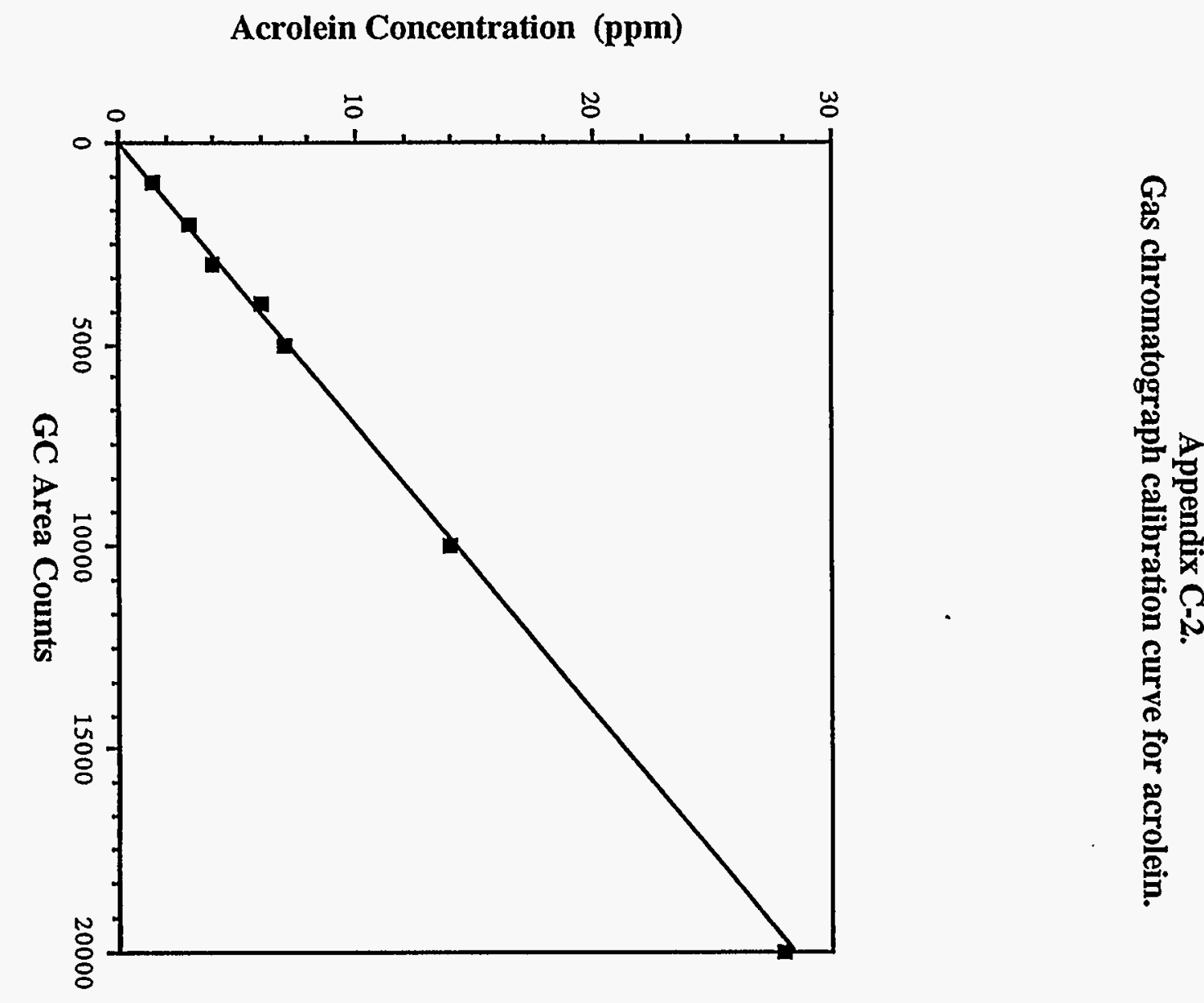


\section{Appendix C-3. \\ Log-Normal probability plot of the upstream particle size data.}

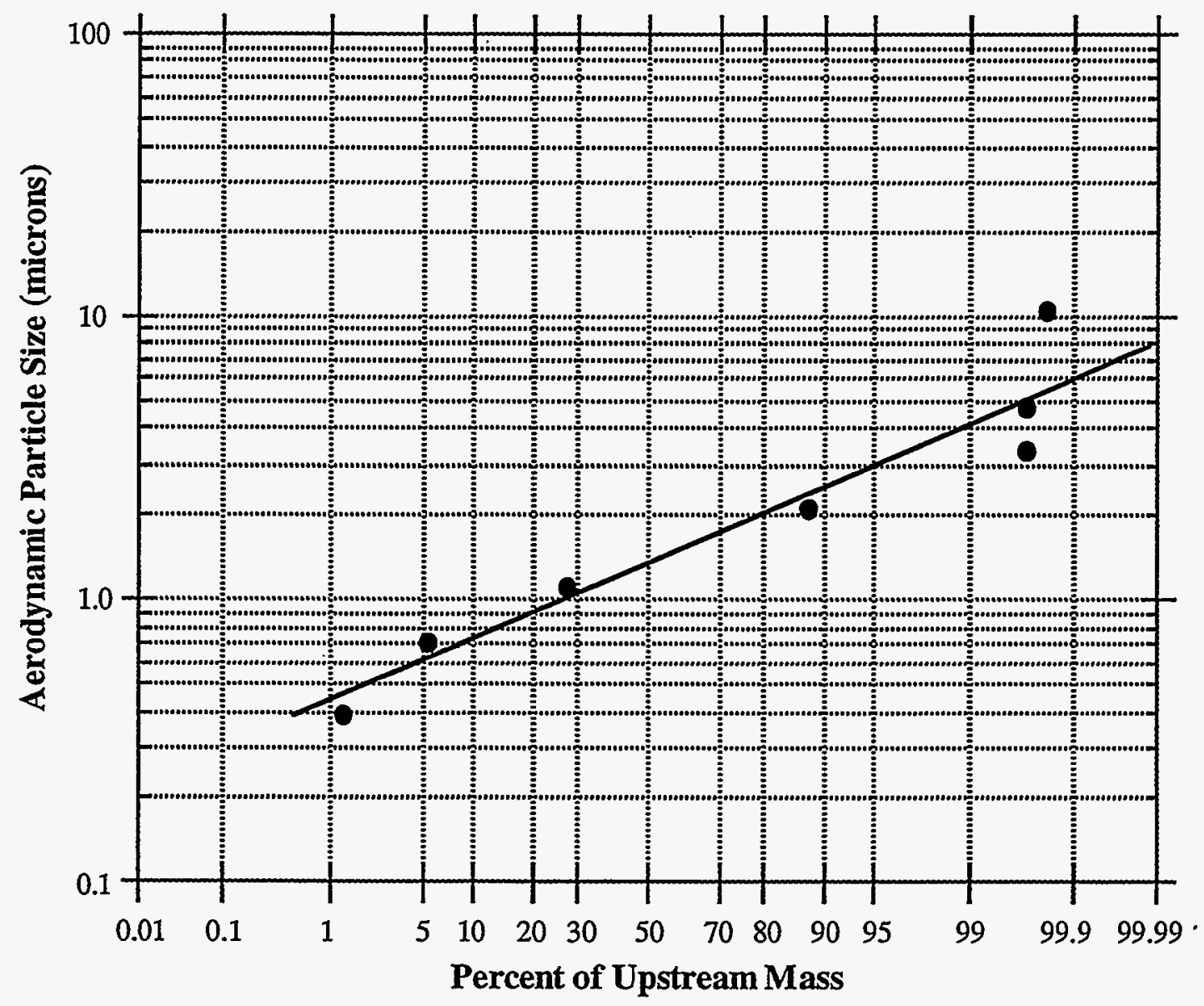




\section{Appendix C-4. \\ Log-Normal probability plot of the downstream particle size data.}

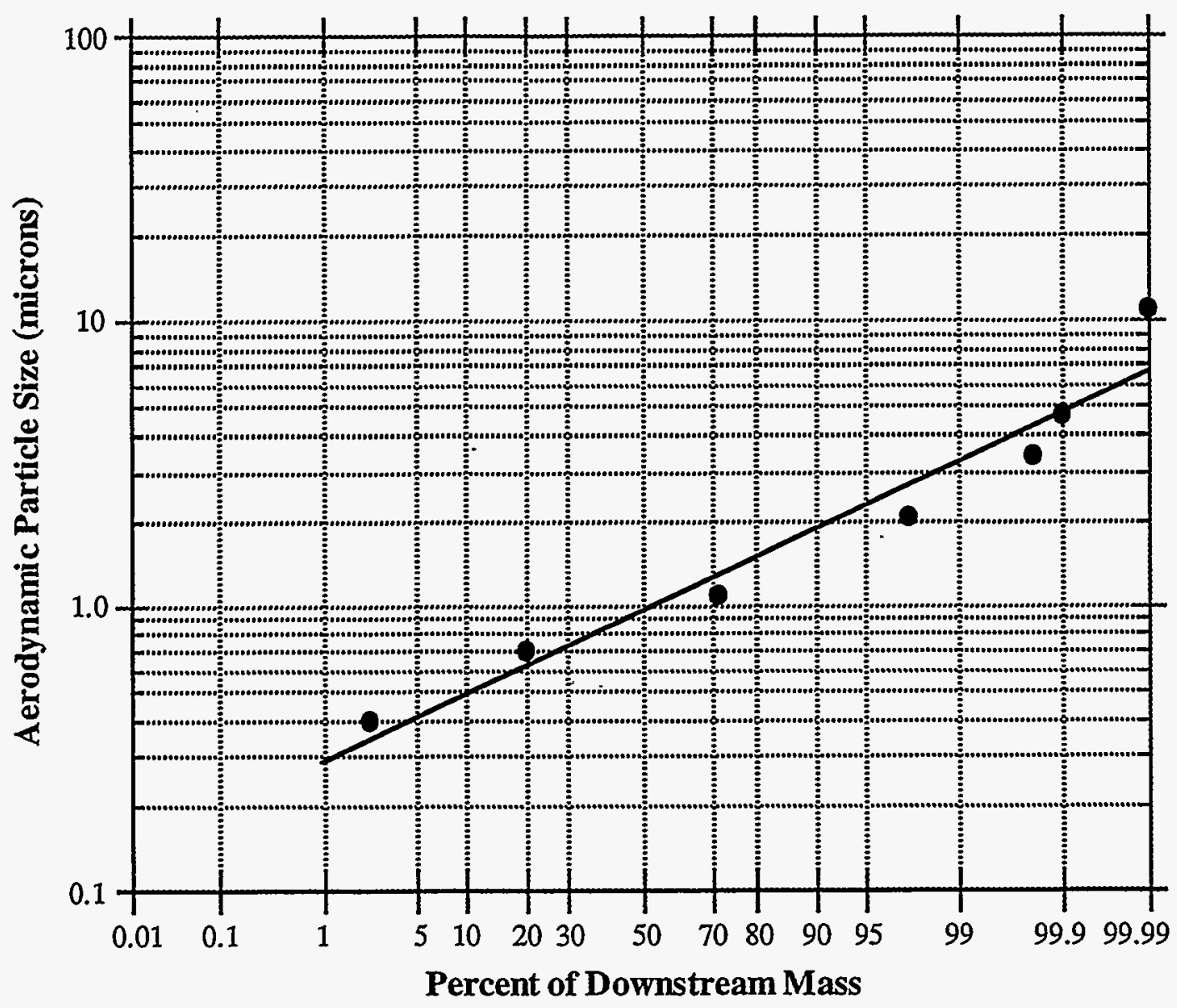


